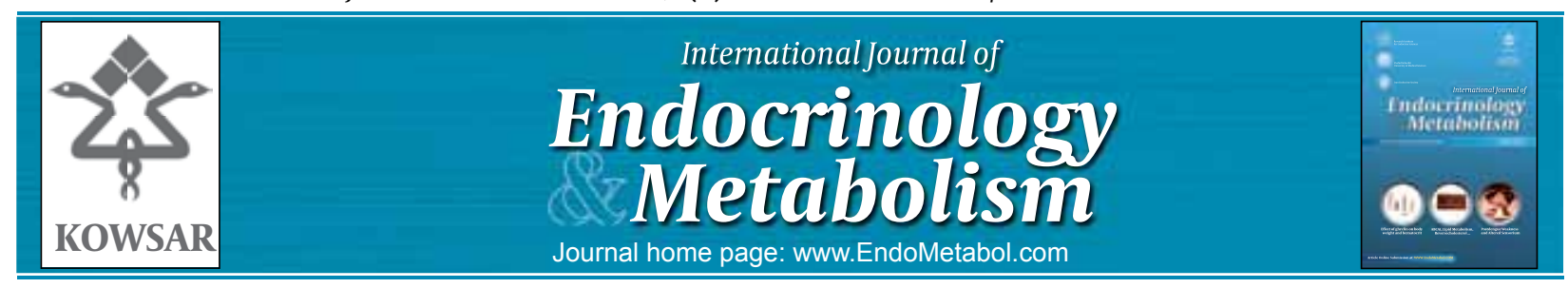

\title{
hCG, the Centerpiece of Life and Death
}

\author{
Laurence A. Cole ${ }^{1^{*}}$ \\ ${ }^{1}$ USA hCG Reference Service, Department of Obstetrics and Gynecology, University of New Mexico, Albuquerque, USA
}

\begin{tabular}{|c|c|}
\hline A R T I C L E I N F O & A B S T R A C T \\
\hline Article type: & \multirow{9}{*}{$\begin{array}{l}\text { hCG is a generic name for } 5 \text { biologically active molecules that share a common } \alpha \text { and } \beta \text { - } \\
\text { subunit amino acid sequence. These } 5 \text { molecules have key biological function in human } \\
\text { pregnancy and human cancer. This review examines these molecule in detail. These } 5 \\
\text { molecules, hCG, sulfated hCG, hyperglycosylated hCG, hCG free } ß \text { and hyperglycosylated } \\
\text { free } ß \text { are produced by placental syncytiotrophoblast cells and pituitary gonadotrope } \\
\text { cells (group 1), and by placental cytotrophoblast cells and human malignancies (group } \\
\text { 2). Group } 1 \text { molecules are both hormones that act on the hCG/LH receptor. These mol- } \\
\text { ecules are central to human menstrual cycle and human pregnancy. Group } 2 \text { molecules } \\
\text { are autocrines that act by antagonizing a TGFß receptor. These molecules are critical to } \\
\text { all advanced malignancies.The hCG groups are molecules critical to both the molecules } \\
\text { of pregnancy or human life, and to the advancement of cancer, or human death. }\end{array}$} \\
\hline & \\
\hline Article history: & \\
\hline Received: 05 Feb 2011 & \\
\hline Revised:30 Feb 2011 & \\
\hline Accepted: 20 Mar 2011 & \\
\hline Keywords: & \\
\hline Human Chorionic Gonadotropin & \\
\hline Cytotrophoblast & \\
\hline
\end{tabular}

Copyright @ 2011 Kowsar M. P. Co. All rights reserved.

- Implication for health policy/practice/research/medical education:

Article shows the multiple functions that hCG variant have in pregnancy, and in normal pituitary function in women. As also shown, hCG variants are misused by all human malignancies to drive growth, invasion and metastases.

- Please cite this paper as:

Cole LA. hCG, the Centerpiece of Life and Death. Int J Endocrinol Metab. 2011;9(2):335-52. DOI: 10.5812/kowsar.1726913X.3398

\section{1. hCG, Two Groups of Molecules With Com- mon Amino Acid Sequences}

It is not easy say who was the discoverer of the placental gonadotropin hCG. In 1912, Aschner stimulated guinea pig genital tracts with injections of extracts of human placenta (1). In 1919, Hirose used immature rabbits and human placental tissue to stimulate ovulation and normal luteal function (2). Both of these studies show a clear link between a hormone produced by the placenta and the uterus. Around this time, the name human chorionic gonadotropin (hCG) was conceived: Chorion comes from latin "chordate" meaning after birth; gonadotropin because the hormone is a gonad-tropic molecule, acting on the ovaries, promoting steroid-induced actions. In 1927, Ascheim and Zondek demonstrated that pregnant

* Corresponding author: Laurence A. Cole, USA hCG Reference Service, Department of Obstetrics and Gynecology, University of New Mexico, Albuquerque, NM 87109, USA. Tel/Fax:+1-5052723576, E-mail: larry@ hCGlab.com DOI:10.5812/kowsar.1726913X.3398

Copyright $\odot 2011$ Kowsar M.P.Co. All rights reserved women produced a gonad-stimulating substance (3). This was in some respects the first finding of hCG. They showed that injecting this molecule into female mice let to follicular maturation and ovulation. We claim in Table 1 all of these authors, Aschner, Hirose, Ascheim and Zondek 1912-1927 as the discoverers of hCG. The review is the incredible story of molecule hCG as we know it today. Table 1 shows major discoveries in the story of hCG (1$36)$. Numerous studies focused on the amino acid sequence of hCG (27), and the N- and O-linked oligosaccharides that form a major part of the hCG structure $(14,26)$. Other major discoveries include the hCG/LH receptor (7, 25 ) and the unraveling of the many biological activities of hCG (24). Possible the intriguing function found for hCG is that it controls growth if the fetus (see Section 2, hCG and pregnancy). Numerous investigators have unraveled the story showing that cancer cells produce an hCG form. This research starts with the finding that cancers produce hCG free $ß$ (17). It goes on to the discovery that all advanced cancers produce hCG free $\beta$ (4). As discovered in 2000 , hCG free $\beta$ promotes cancer cell growth 
and malignancy by antagonizing a TGFß receptor, a different receptor to the hCG/LH receptor. Other major discoveries include the finding of a common $\alpha$-subunit gene on chromosome 6 (20), of a ß-subunit gene on chromosome 19 (12), and of the hCGß-LHß complex genes on chromosome 19 (29) (Table 1). As described, the first hCG test, a biological activity test, was discovered in 1930 (36), and the original hCG antibody agglutination test was discovered in 1960 (35). The initial hCG radioimmunoassay was discovered in 1967 (6). The initial radioimmunoassay cross-reacted with $\mathrm{LH}$ (6). Vaitikaitis and colleagues developed the hCGß radioimmunoassay, which differed hCG from LH (33). Free $\alpha$-subunit and free ß-subunit were discovered as secreted molecules in 1978 (21). The carbohydrate structure that prevents free $\alpha$-subunit combination with ß-subunit was described in 1985 (10). Seemingly, the oddest discovery was that some hCG variants function independent to the hormone hCG $(9,13,15,16)$. As shown, hyperglycosylated hCG promotes cytotrophoblast cell growth during pregnancy, and drives pregnancy implantation/ This molecule has independent functions to hCG $(16,37-40)$. As recently demonstrated, hyperglycosylated hCG functions as pregnancy implantation promoter and hCG free $ß$ functions as a cancer promoter, both function by antagonizing a TGFß receptor, rather than acting on the hCG/LH receptor $(13,15)$. Multiple forms of hCG include sulfated forms of hCG that is produced by the pituitary gland, during the menstrual cycle $(9,31)$. These sulfated hCG molecules are hormones like hCG, acting on the LH/hCG receptor. Sulfated hCG supplements LH during the menstrual cycle (31).

As shown in Table 2. there are 5 clear variants of hCG, produced by different cells and having separate functions. These are all molecules that share a common amino acid sequence with hCG. I remember that with the discovery of the first independent variant, hyperglycosylated hCG, produced by different cells and having separate functions (16), I initially gave it a separate name, Invasive Trophoblast Antigen. This name was used for 2 years, until World Health Organization (WHO) informed me that it had to have a name that included the term hCG, since it had an identical amino acid sequence to hCG. This is such a strange situation, hCG binds the LH/hCG receptor and hyperglycosylated hCG antagonizes a TGFß receptor. Two separate molecules with a common amino acid sequence. I promptly renamed it hyperglycosylated hCG. I assume the same rule must apply to all 5 hCG variants. The hCG variants all vary in meric structure (number of subunits) and carbohydrate structure (Table 2). hCG is the most glycosylated glycoprotein known. The hCG dimer comprises $30 \%$ sugars or oligosaccharides by molecular weight, hyperglycosylated hCG comprises 39\% oligosaccharides, and hyperglycosylated free $ß$ comprises $42 \%$ oligosaccharides by molecular weight. Of the 5 biologically active variants, hCG is made by placental syncytiotro- phoblast cells, sulfated hCG made by pituitary gonadotrope cells, hyperglycosylated hCG made by placental cytotrophoblast cells, hCG free $ß$ made by malignancies and hyperglycosylated free $\beta$ made by malignancies. These 5 variants can be classed into two general types of molecules. hCG and sulfated hCG are endocrines, acting on an hCG/LH receptor during pregnancy (hCG) and during the menstrual cycle (sulfated hCG) $(9,31,41)$. Hyperglycosylated hCG, hCG free $ß$ and hyperglycosylated free $B$, in contrast, are all autocrines, acting on the TGFß receptor on the cells that produce the molecules $(13,16,37)$. So there are the hCG endocrines and the hCG autocrines. The autocrines are all cancer promoters (15).

hCG is composed of a 92 amino acid $\alpha$-subunit with 2 N-linked oligosaccharides, and a non-covalently linked 145 amino acid ß-subunit with $2 \mathrm{~N}$-linked oligosaccharides and 4 O-linked oligosaccharides $(27,42,43)$. The structure of each variant of hCG varies considerable in carbohydrate structure $(42,43)$. The structures produced in cancer cases, choriocarcinoma and other malignancies include larger hyperglycosylated structures, with triantennary N-linked oligosaccharides and more complex O-linked oligosaccharides $(14,26,42,43)$. hCG molecules also vary greatly in charge (44), due to variation in sialic acid sugar content. As if that is not enough heterogeneity there is another major source for hCG heterogeneity. hCG is nicked and dissociated immediately after secretion by macrophages, leukocytes and monocytes (45). These accumulate around placental trophoblast cells. The enzyme human leukocyte elastase is produced by macrophages, leukocytes and monocytes. It cleaves hCG-related molecules at $\$ 45-46$ or $ß 47-48$ (45). This same enzyme then cleaves the hCG ß-subunit C-terminal peptide at \$92-93 leading to the release of the ß-subunit C-terminal peptide $(5,46,47)$. Add to this hCG dissociation, and the more rapid dissociation following nicking by leukocyte elastase (45) and one has the major pathways of hCG degradation. In kidneys, following nicking or cleavage of the ß-subunit C-terminal peptide in serum, exoglycosidases clear ß39-47 and ß4855 , leukocyte elastase, the nicking enzyme, cleaves ß5-6. What appears in urine is ß-core fragment, the terminal degradation product of hCG variants. ß-core fragment comprises ß-subunit 6-38, disulfide linked to ß55-ß92.

Adding everything together, hCG exist as 5 independent biologically active molecules. Each of these may be synthesized as fully sialylated, incompletely sialylated, partially sialylated and minimally sialylated variants. Five molecules times 4 extents of sialylation is 20 molecules. Once secreted, each of these may nicked or not nicked at ß44-45 or ß47-48, taking us from 20 molecules to 60 molecules. These may remain intact in the circulation or dissociated as free ß-subunit, bringing us to 120 circulating, molecules. These may be cleaved and loose their C-terminal peptide bring us up to a mixture of 240 circulating molecules. When one considers immunoassays for detecting total hCG in serum. What an impossi- 


\begin{tabular}{|c|c|c|}
\hline $\begin{array}{l}\text { Aschner, Hirose, Ascheim and Zondek } \\
(1-3)\end{array}$ & First discovery of placental ovarian gonadotropin, hCG & $1912-1927$ \\
\hline Zondek B, Ascheim S (36) & First hCG test, the Zondek-Ascheim Pregnancy Test & 1930 \\
\hline Wide L, Gemzell CA (35) & First immunological pregnancy test, an antibody agglutination test & 1960 \\
\hline Aono T, et al (6) & First hCG radioimmunoassay & 1967 \\
\hline Swaminathan N, et al (32) & Discovery that hCG is a non-covalently linked dimer & 1970 \\
\hline Vaitukaitis JL, et al (33) & Discovery of hCGß radioimmunoassay, assay only detects hCG & 1972 \\
\hline Morgan FJ, et al (27) & Discovery of the amino acid structure of hCG & 1975 \\
\hline Franchimont $\mathrm{P}$, et al (21) & Production of hCG free $\alpha$-subunit and free ß-subunit & 1978 \\
\hline Fiddes JC, et al (100) & Discovery of hCG evolution among primates & 1980 \\
\hline Wehmann RE, et al (34) & Discovery of hCG metabolic clearance rate & 1981 \\
\hline Fiddes JC, et al (20) & Discovery of common $\alpha$-subunit gene & 1981 \\
\hline Boorstein W, et al (12) & hCG ß-subunit gene structure & 1982 \\
\hline Mizouchi T, et al (26) & Discovery of the N-linked carbohydrate structure of hCG & 1983 \\
\hline Cole LA, Hartle Ret al (17) & $\begin{array}{l}\text { Discovery that free } ß \text { subunit detected in cancer cell lines, and detected in } \\
\text { cancer patient serum and urine }\end{array}$ & 1983 \\
\hline Hussa RO, et al (22) & First hCG immunometric assay & 1984 \\
\hline Amr CE, et al (5) & $\begin{array}{l}\text { Discovery of ß-core fragment and of free hCGß C-terminal peptide, hCG } \\
\text { breakdown products in urine }\end{array}$ & 1984 \\
\hline Blithe DL, et al (10) & alternative structure of hCG free $\alpha$-subunit, why does not combine with $ß$ & 1985 \\
\hline Policastro PF, et al (29) & Map of hCG and LH genes & 1986 \\
\hline Bogart $\mathrm{MH}$, et al (11) & hCG as a marker of Down syndrome pregnancy & 1987 \\
\hline Odell WD, et al (31) & $\begin{array}{l}\text { Demonstration that pituitary gland produced hCG during menstrual } \\
\text { cycle }\end{array}$ & 1987 \\
\hline Cole LA (14) & Discovery of the O-linked carbohydrate structure of hCG & 1987 \\
\hline Nishimura R, et al (28) & Discovery of Nicked hCG & 1988 \\
\hline Ascoli M, et al (7) & Discovery hCG/LH receptor and its mode of action & 1989 \\
\hline McFarland RC et al. (25) & Discovery hCG/LH receptor and its mode of action & 1989 \\
\hline Lei ZM, et al (24) & Discovery of multiple biological functions for hCG & 1992 \\
\hline Lapthorn AJ, et al (23) & $\begin{array}{l}\text { Discovery of hCG 3D structure, demonstration that it contains common } \\
\text { structures with TGFß, PDGF and NFG }\end{array}$ & 1994 \\
\hline Acevedo HF, et al (4) & Discovery that all cancers produce an hCG-related molecule & 1996 \\
\hline Birken S, et al (9) & Discovery of sulfated hCG produced by pituitary with reduced bioactivity & 1996 \\
\hline O'Connor JF, et al (30) & Discovery that hyperglycosylated hCG predominates in early pregnancy & 1998 \\
\hline Butler SA, Iet al (13) & $\begin{array}{l}\text { Discovery that cancer cell hCG free ß acts separately to hCG, antagonizing } \\
\text { cancer cell TGFß receptor }\end{array}$ & 2000 \\
\hline Birken $S$, et al (8) & Establishment of pure hCG standards & 2003 \\
\hline Cole L, et al (16) & Discovery of hyperglycosylated hCG as an independent molecule to hCG & 2006 \\
\hline Cole LA, et al (18) & Discovery of the role of hCG in human evolution & 2008 \\
\hline Cole LA, et al (15) & $\begin{array}{l}\text { That hyperglycosylated hCG, hCG free } ß \text { and hyperglycosylated free } ß \text { are } \\
\text { interchangeable cancer promoters, all antagonizing a TGFß receptor }\end{array}$ & 2011 \\
\hline
\end{tabular}

ble job, appropriately detecting 240 different variants of hCG.

Most hCG-related molecules are cleared from the circulation by liver. As estimated, 78\% of hCG-related molecules are cleared by the human liver (48). Molecules deficient in sialic acid sugar residues are cleared through the liver galactose receptor (49). All told the liver and the renal urinary ß-core fragment clearance system clear all hCG-related molecules

hCG enzyme immunometric assays include the 12 automated platform assays used by every clinical laboratory all over the world (Abbott Axsym system, Abbott Architect system, Beckman Access system, Beckman DxI 800 system, Ortho Vitros ECiQ system, Roche Elecsys 


\begin{tabular}{|c|c|c|c|c|c|}
\hline & hCG & Sulfated hCG & $\begin{array}{l}\text { Hyperglycosylated } \\
\text { hCG }\end{array}$ & hCGß & $\begin{array}{l}\text { Hyperglycosylated } \\
\text { hCGß }\end{array}$ \\
\hline Source cell & $\begin{array}{l}\text { Syncytiotro- } \\
\text { phoblast }\end{array}$ & Gonadotrope & Cytotrophoblast & $\begin{array}{l}\text { Advanced malig- } \\
\text { nancy }\end{array}$ & $\begin{array}{l}\text { Advanced malig- } \\
\text { nancy }\end{array}$ \\
\hline Mode of action & Endocrine & Endocrine & Autocrine & Autocrine & Autocrine \\
\hline Type of molecule & $\begin{array}{l}\text { hCG Endo- } \\
\text { crine }\end{array}$ & hCG Endocrine & hCG autocrine & hCG autocrine & hCG autocrine \\
\hline Total molecular weight & 37,180 & 36,150 & 42,800 & 23,300 & 27,600 \\
\hline Site of action & $\begin{array}{l}\text { LH/hCG recep- } \\
\text { tor }\end{array}$ & LH/hCG receptor & TGFß antagonism & $\begin{array}{l}\text { TGFß antago- } \\
\text { nism }\end{array}$ & TGFß antagonism \\
\hline Amino acids $\alpha$-subunit & 92 & 92 & 92 & - & - \\
\hline Amino acids ß-subunit & 145 & 145 & 145 & 145 & 145 \\
\hline $\begin{array}{l}\text { Peptide molecular } \\
\text { weight }\end{array}$ & 26,200 & 26,200 & 26,200 & 16,000 & 16,000 \\
\hline $\begin{array}{l}\text { O-linked oligosaccha- } \\
\text { rides }\end{array}$ & 4 & 4 & 4 & 4 & 4 \\
\hline $\begin{array}{l}\mathrm{N} \text {-linked oligosaccha- } \\
\text { rides }\end{array}$ & 4 & 4 & 4 & 4 & 4 \\
\hline $\begin{array}{l}\text { Molecular weight } \\
\text { sugars }\end{array}$ & 10,980 & 9,950 & 16,600 & 7,300 & 11,600 \\
\hline Sugars, \% & 30 & 28 & 39 & 31 & 42 \\
\hline $\begin{array}{l}\text { Isoelectric point (pI), } \\
\text { principal peak }\end{array}$ & 3.5 & Not known & 3.2 & Not known & 3.5 \\
\hline $\begin{array}{l}\text { Metabolic clearance } \\
\text { rate, } \mathrm{h}\end{array}$ & 36 & 20 & Not known & 0.72 & Not Known \\
\hline
\end{tabular}

Amino acid content, molecular weight and sugar contents determined from published structures as determined by elliott, et al. for hCG and hyperglycosylated hCG (42), Birken et al. for Sulfated Pituitary hCG (9) and Valmu et al. for Hyperglycosylated hCGß (43).

The molecular weight of common hCG dimer amino acid backbone is that as determined by Morgan et al. (27). Molecular weight of N-and O-linked sugar side chains is added to these values. Isoelectric points are those published by Sutton et al. (44) and metabolic clearance rate are those established by Wehmann and Nisula (34). Modes of action are sites of action are as published $(8,9,13,15,41)$.

system, Siemens ACS180 system, Siemens Centaur, Siemens Dimension Vista system, Siemens Immulite system, Siemens Status system and Tosoh A1A system). It is amazing, how these automated assays detect these extremes of heterogeneity with the existence of as many as 240 hCG variants in human blood. The answer is that they do not, and this confuses serum total hCG results accordingly. In general $(50,51)$, all assays appropriately detect intact hCG, but invariable detect or do not detect nicked hCG, hyperglycosylated hCG, nicked hCG missing the C-terminal peptide, hCG free ß-subunit, nicked hCG free ß-subunit, ß-core fragment, and hCG deficient in or variable in sialic acid. The only exception that we are aware of is the hCG Immulite systems (Immulite $1000,2000,2500]$ total hCG assay, and the old hCGß radioimmunoassay. These are only assays that detect all of these major hCG variants $(50,51)$.

In conclusion, hCG is an extremely heterogeneous molecule. This review examines these molecules in detail. While hCG is clearly the key hormone in pregnancy, variants such as sulfated hCG are key to pituitary functions. hCG free $\beta$ and hyperglycosylated are seeming key promoters in human cancer biology.

\section{2. hCG and Hyperglycosylated hCG, the Po- tent Growth, Angiogenic and Invasion Fac- tors That Drive Human Pregnancy}

hCG and hyperglycosylated hCG are the endocrine and the autocrine which control pregnancy. Of the 5 hCG variants described in Table 2, just these two drive multiple aspects of pregnancy. Pregnancy, of course, is always detected by a total hCG test, with the initial detection of primarily hyperglycosylated hCG) or the much less concentration of hCG) on the day of implantation (52-54). Figure 1 shows the logarithmic levels of the hormone hCG and the autocrine hyperglycosylated hCG produced during pregnancy (5254). The initial placental cells or root cells are mononuclear cytotrophoblast cells. The cell produce hyperglycosylated hCG. These cells fuse forming differentiated polynuclear syncytiotrophoblast cells. These differentiated cells produce hCG. New placenta is being generated throughout the course of pregnancy so that new cytotrophoblast cell are produced making hyperglycosylated hCG and then fused to make cells that produce hCG. As a result, hCG and hyperglycosylated hCG are produced through the length of pregnancy (Figure 1). The new placenta that 


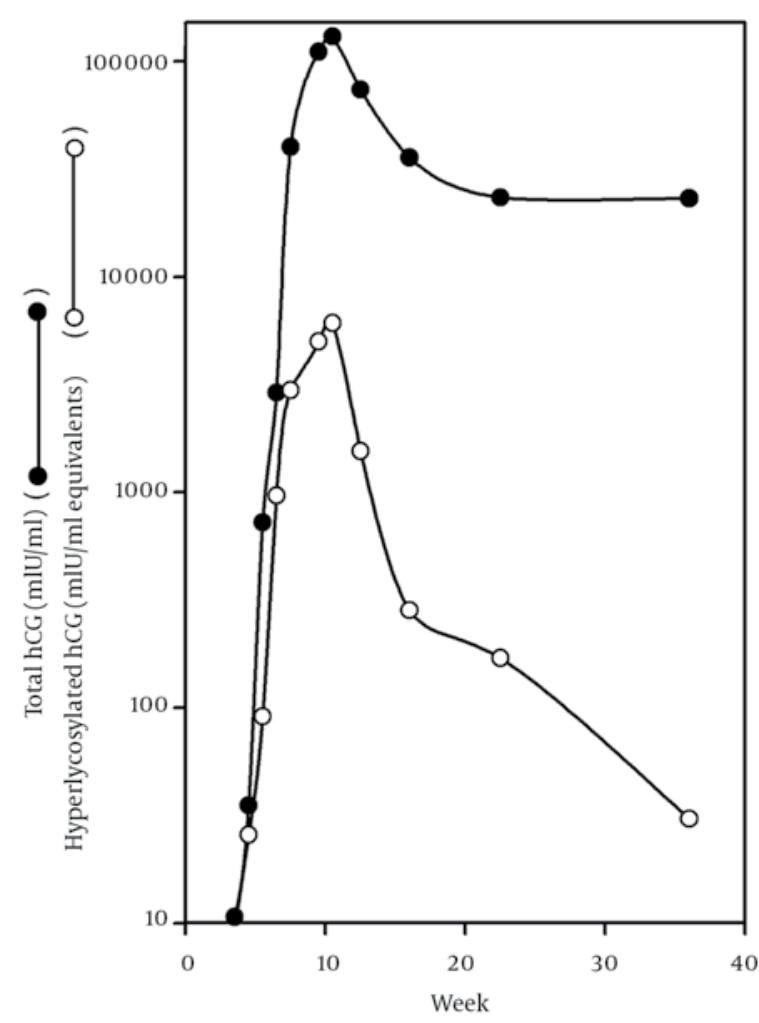

Figure 1. Serum Median Concentration of Total hCG $(\bullet)$ and Hyperglycosylated hCG (O) Produced During Pregnancy (n=536) [52-54].

is implanted comprises of mostly root cytotrophoblast cells. As such, hyperglycosylated hCG comprise 90\% of serum total hCG in the 3rd week of gestation or the week following implantation of pregnancy. Hyperglycosylated hCG comprises $73 \%$ of total hCG at 4 weeks, $50 \%$ of total hCG at 6 weeks dropping down to $10 \%$ hyperglycosylated hCG at 10 weeks gestation and $1 / 2 \%$ hyperglycosylated hCG in the third trimester of pregnancy (52-54). Both hCG and hyperglycosylated hCG peak at around 10 weeks of gestation. At peak, total hCG concentration is close to 100,000 $\mathrm{mIU} / \mathrm{ml}$ or almost 40,000-fold greater than mean implantation hCG levels. hCG is the only know molecule to be stimulated so greatly. Hyperglycosylated hCG levels at peak are approximately $8,000 \mathrm{mIU} / \mathrm{ml}$ equivalents, or just 1,500-fold amplified over implantation concentration. Following the peak, hCG and hyperglycosylated hCG concentrations drop significantly. hCG and hyperglycosylated hCG levels can vary very greatly between individual pregnancies. At 4 weeks gestation, total hCG levels in term outcome pregnancies can vary from 2.0 to $1760 \mathrm{mIU} / \mathrm{ml}$ or vary by 888 -fold, at 5 weeks gestation total hCG levels can vary from 11 to $7680 \mathrm{mIU} / \mathrm{ml}$ or vary by 700 fold, and at 6 weeks of gestation can vary from 8.4 to $6920 \mathrm{mIU} / \mathrm{ml}$ or vary by 820 -fold (55). How can normal term outcome hCG concentration vary so greatly? As demonstrated, variation comes from inappropriately dating pregnancies, dating them to the start of the last menstrual period rather than to day of implantation (start of appearance of low concentrations of hCG) (55). The other issue that cause the wide variation in hCG levels is that individual pregnancies amplify hCG differently. In some pregnancies cells amplify total hCG in early pregnancy as slow as 1.52-fold per day over multiple days, while in other pregnancies hCG may be amplified by as much as 2.92-fold over multiple days (53). It appears that both of these factors, together cause the wide variation in individual hCG production in normal term pregnancy (53). A separate major factor copes with making sure all pregnancies are normal and that hCG critical biological activities can cope with these wide variations. This is the spare receptor theory (56-58). Under the spare receptor theory, when a small proportion of receptors is activated it may yield similar cellular response to when all receptors are activated (56-58). This is due to plateaus in receptor G protein and cyclic AMP response (56-58). Similarly, the low progesterone production produced in response to high concentrations of hCG may be explained by down-regulation $(59,60)$. As demonstrated, high concentrations of hCG decrease the number of receptor on cells by degrading the receptor transcript rate. A significant decrease has been observed in half-life of receptor transcript (59). This may explain the low progesterone production in pregnant women with high total hCG levels. Together, the spare receptor and down-regulation theories explain how the hCG/LH receptor copes with the extreme of total hCG concentrations. The 3 dimensional structure of hCG is shown in Figure 2 (23). As shown, the 145 amino acid ß-subunit folds itself around the 92 amino acid $\alpha$-subunit in a non-covalent manner. A clear

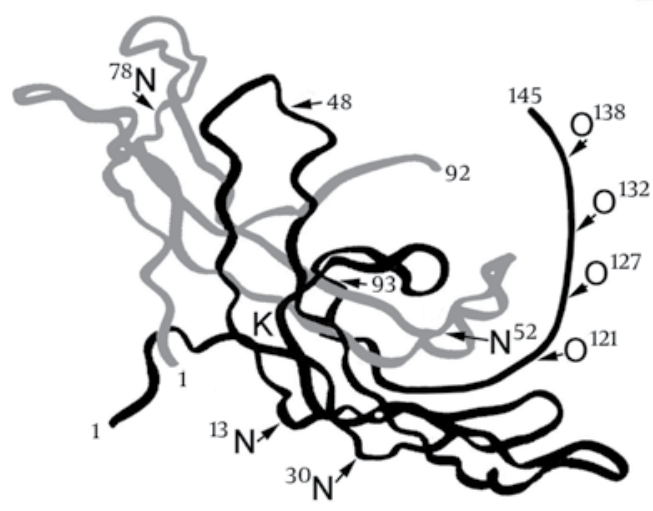

Figure 2. Crystal Structure of Deglycosylated Regular hCG, as Shown by Lapthorn, et al. (23).

The unfolded ß-subunit C-terminal peptide is added (missing in crystal structure). It is inferred that this structure is not folded since the sequence comprises primarily a polymer of proline and serine residues. The symbol $\mathrm{N}$ indicate the site of attachment of $\mathrm{N}$-linked oligosaccharides, and the symbol O the attachment site of O-linked oligosaccharides. Residue $ß 48$ is indicated, the site of nicking of hCG (ß47-48), and residue ß93, the site of cleavage of the ß-subunit C-terminal peptide(ß92-93). The symbol K indicates the site of the cystine knot structure, 4 peptides ß1-15, ß30-45, ß80-100, and ß50-65 linked by 3 disulfide bridges, $334-88$, ß9-57 and ß38-90. The $\alpha$-subunit is shown in grey, and ß-subunit in black. 
N-linked oligosaccharides

\section{O-linked oligosaccharides}

\section{hCG and hCGß}

${ }_{3}^{6}$ Man ß1,4 GIcNAc ß1,4 GIcNAc-N-Asn

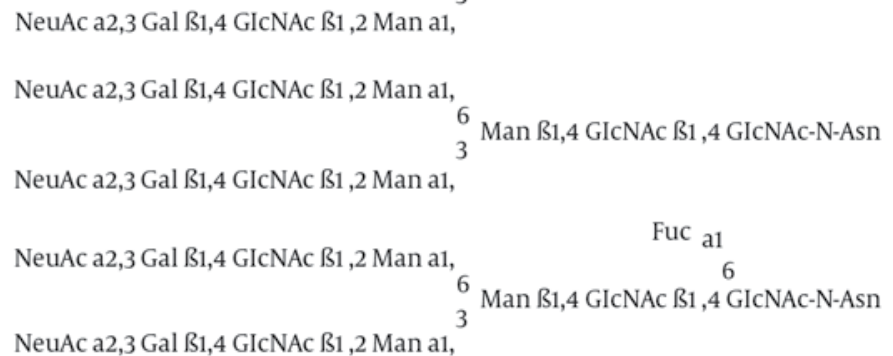

NeuAc a2,3 Gal ß1,4 GIcNAc ß1, 2 Man a1,

${ }_{3}^{6}$ Man ß1,4 GIcNAc ß1 ,4 GIcNAc-N-Asn

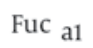

Figure 3. Structure of N-linked Oligosaccharides and O-linked Oligosaccharides Attached to hCG (and hCG Free ß), and Hyperglycosylated hCG.

structural arm of ß-subunit, residues 60-95 literally folds around $\alpha$-subunit, like it cuddles or hold on to this subunit. The crystal structure had to be determined on deglycosylated hCG. Figure 3 shows the structure of sugars or oligosaccharides attached to hCG $(42,43)$. As shown, hCG has primarily monoantennary and biantennary Nlinked oligosaccharides, and trisaccharide and tetrasaccharide O-linked oligosaccharides.

hCG and hyperglycosylated hCG drive almost every aspect of pregnancy. The big exception is balancing nutrients during pregnancy, human placenta lactogen (hPL) and human placental growth hormone (hPGH), two growth hormone analogs, fill this critical function, balancing glucose supply and amino acid supply reaching the fetus in a pregnant woman. For some reason, all reproductive biology and obstetrics and gynecology text books sold today claim that maintaining the corpus luteum during early pregnancy is the sole job of hCG. This is grossly incorrect, over 200 solid publications show and confirm and confirm again that hCG and hyperglycosylated hCG performs a very large number of key roles during pregnancy (1-3, 16, 24, 37-40, 61-98). As shown in Table
3, hCG and hyperglycosylated hCG control many aspects of pregnancy (1-3, 16, 24, 37-40, 61-98). hCG maintains corpus luteal progesterone production during pregnancy. hCG and hyperglycosylated hCG together control establishment of ultra-efficient hemochorial placentation. hCG and hyperglycosylated hCG control villous placental formation, and hCG promotes uterine spiral blood vessels, and generates umbilical blood vessels, to meet the villous placental structures. hCG controls uterine growth during pregnancy and suppresses immunorejection of the foreign fetoplacental unit. hCG suppresses contractions during pregnancy, and hyperglycosylated hCG controls implantation of pregnancy. Most of all, multiple researchers have identified hCG receptors on fetal organs, and have located a fetal source of hCG production. It is indicated that hCG is the key fetal growth factor during pregnanxy. All told, hCG is the critical pregnancy factor (1-3, 16, 24, 37-40, 61-98). Starting at implantation of pregnancy, hCG takes over from LH maintenance of corpus luteal progesterone production $(1,2,63,75,78,81,82,86$, $91,95)$. This continues for just 3-4 weeks in pregnancy. With time, placenta matures with fusion and differen- 


\begin{tabular}{|c|c|c|}
\hline Signal Molecule & Function & References \\
\hline \multicolumn{3}{|l|}{ hCG } \\
\hline & $\begin{array}{l}\text { 1. Promotion of corpus luteum progesterone production } \\
\text { 2. Angiogenesis of uterine vasculature } \\
\text { 3. Cytotrophoblast differentiation } \\
\text { 4. Immuno-blanding and blockage of phagocytosis of invading tropho- } \\
\text { blast cells } \\
\text { 5. Growth of uterus in line with fetal growth } \\
\text { 6. Quiescence of uterine muscle contraction } \\
\text { 7. Promotion of growth and differentiation of fetal organs } \\
\text { 8. Blastocysts signal decidua prior to implantation } \\
\text { 9. Umbilical cord growth and development } \\
\text { 10. hCG in sperm and receptors found in fallopian tubes suggesting pre- } \\
\text { pregnancy communication } \\
\text { 11. hCG receptors in brain hippocampus, hypothalamus and brain stem, } \\
\text { cause of pregnancy nausea/vomiting }\end{array}$ & $\begin{array}{l}(1-3,63,75,78,81,82,86,91,95) \\
(24,64,74,92,93,97,98) \\
(90) \\
(62,67,77) \\
(89,96) \\
(66,69,70,89) \\
(60,61,72,79,89) \\
(80,84,89) \\
(87,88,94) \\
(68,71,76) \\
(76,79,83,85)\end{array}$ \\
\hline \multicolumn{3}{|c|}{ Hyperglycosylated hCG } \\
\hline & $\begin{array}{l}\text { 1. Blocks apoptosis in cytotrophoblast cells } \\
\text { 2. Promotes invasion process by cytotrophoblast cells } \\
\text { 3. Promotes implantation of pregnancy } \\
\text { 4. Promotes growth of cytotrophoblast cells }\end{array}$ & $\begin{array}{l}(73) \\
(16,37-39) \\
(16,37-40) \\
(16,37-40)\end{array}$ \\
\hline \multicolumn{3}{|c|}{$\begin{array}{l}\text { hCG + hyperglycosylated } \\
\text { hCG }\end{array}$} \\
\hline & $\begin{array}{l}\text { Together promotes cytotrophoblast growth and fusion to form villous } \\
\text { placenta. This then fuses with promoted uterine circulation and promot- } \\
\text { ed umbilical circulation to initate hemochorial placentation. }\end{array}$ & $\begin{array}{l}(15,16,37,64,65,68,74,87,88 \\
90,92-94,97,98)\end{array}$ \\
\hline
\end{tabular}

tiation becoming villous placental tissue. This then takes over production of progesterone. Clean transfers occur without a nick in progesterone levels from rising corpus luteal LH-promoted progesterone to rising hCG-promoted progesterone with implantation, and then rising syncytiotrophoblast progesterone after the 6th-7th week of gestation.

One of the key jobs the hormone hCG in pregnancy, joint with hyperglycosylated hCG, is establishment of the ultra-efficient fetal nutrient exchange or hemochorial placentation. The reason why it is called ultra-efficient are explained under Section 3, hCG and Evolution (18). This explains how hemochorial placentation has to be increased in primates to the highest possible efficiency to accommodate human brain development. As shown in Figures 4 and 5 villous placenta is first generated. At the same times as hCG promotes villous formation it promotes uterine angiogenesis and formation of the umbilical circulation. These all meet to initiate hemochorial placentation. Figure 4 Panel A shows cytotrophoblast columns in conceptus promoted by hyperglycosylated hCG $(15,16$, 37-40). Figure 4 Panels B and C shows columns of cytotrophoblast cell protruding from this tissue. The growing column become differentiated around the edges promoted by hCG, to form syncytiotrophoblast tissue (90). As a result of this process villous structures are formed, see $\mathrm{Fi}$ gure 4 Panels C and D. Once villous structures are formed they combine with growing umbilical and maternal circulations to initiate hemochorial placentation. hCG promotes growth or angiogenesis of uterine arteries to meet this growing villous tissue $(24,64,74,92,93,97,98)$. hCG also controls the growth of umbilical vasculature to meet this developing hemochorial placentation. Figure 5 illustrates active hemochorial placentation, where the villous trophoblast meets with maternal spiral arteries and a umbilical circulation. This process comprises 3 of hCG's prime functions (Functions 2,3 and 9 in Table 3) and 1 of hyperglycosylated hCG prime functions. Other critical hCG functions include the immuno-blanding of the feto-plancetal unit and blockage of phagocytosis by macrophages $(62,67,77)$. hCG makes sure that the uterus grows and does not stretch, in line with fetal growth (89, 96). hCG also inhibits myometrial muscle contractions during the course of pregnancy $(66,69,70,89)$. hCG levels drop to their lowest concentration at parturition (Figure 1), permitting oxytocin and prostaglandin promotion of contractions. There is extensive evidence suggesting that hCG may function prior to implantation of pregnancy. hCG has been found in sperm, and hCG/LH receptors found in fallopian tubes $(68,71,76)$. Interestingly, it has been demonstrated that blastocysts use hCG to signal the decidua that they are awaiting implantation, prior to implantation $(80,87,89)$. This strange interuterine space signaling may prepare the decidua for implantation. What promotes fetal growth during pregnancy has always been a conundrum. Growth hormone is inactive in pregnancy, and hPL and hPGH are maternal hormones and have very limited action on fetal growth. Multiple recent studies by different investigators show that fetal organs contain hCG receptors $(61,72,79,83,89)$. It is inferred that hCG is the fetal growth factor and that 

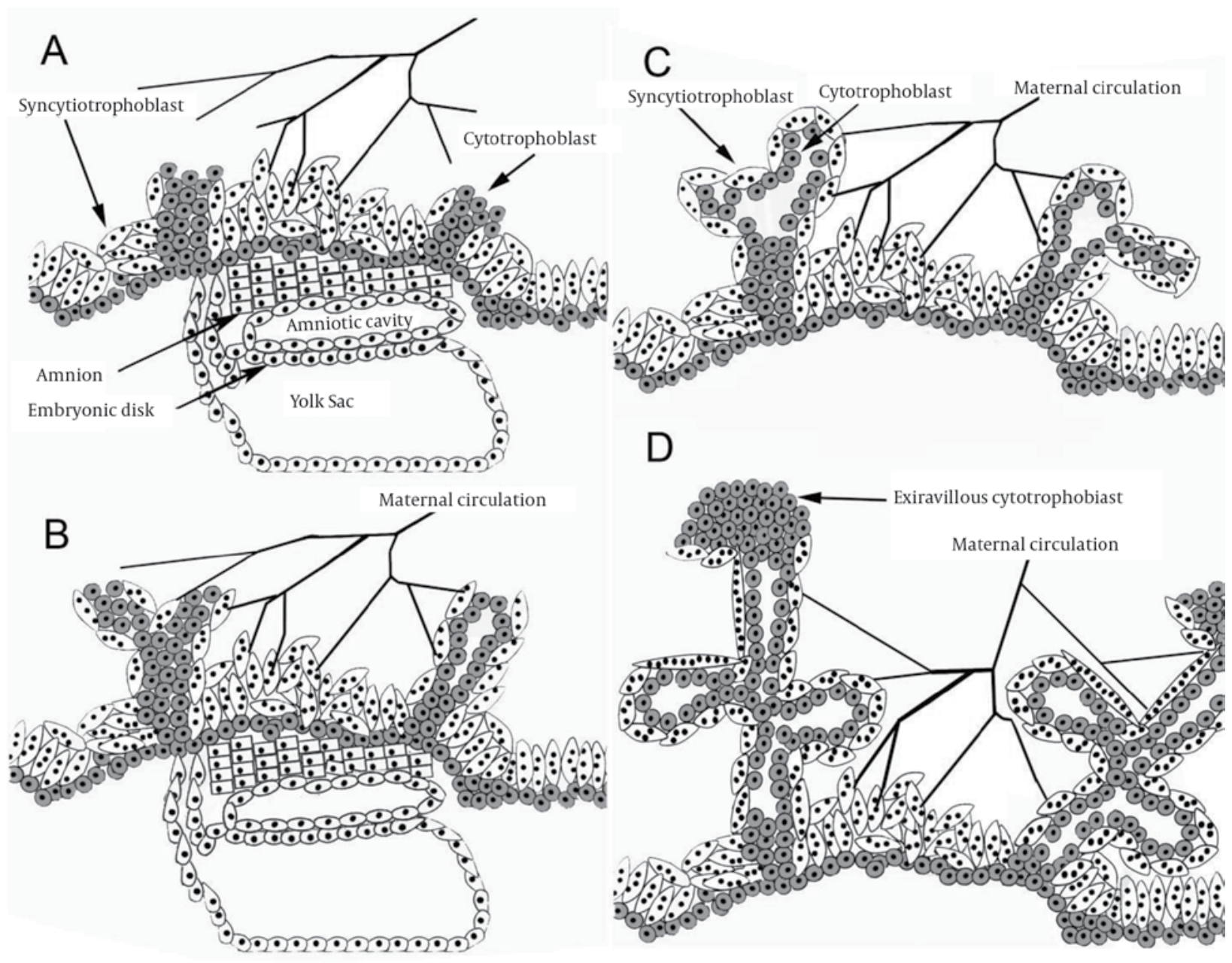

Figure 4. hCG Function in Villous Trophoblast Tissue Formation.

Hyperglycosylated hCG function to promote cytotrophoblast tissue synthesis (15, 16, 37-40), hcg then function to promote fusion and differentiation of this tissue to multinucleated syncytiotrophoblast cells (90).

Panel A shows cytotrophoblast columns in conceptus placental tissue promoted by hyperglycosylated hCG. As shown in Panels B and C columns of cytotrophoblast cell protrude from the tissue, this differentiates around the edges, promoted by hCG, to form syncytiotrophoblast tissue. As a result of this process villous structures are formed (Panels C and D).

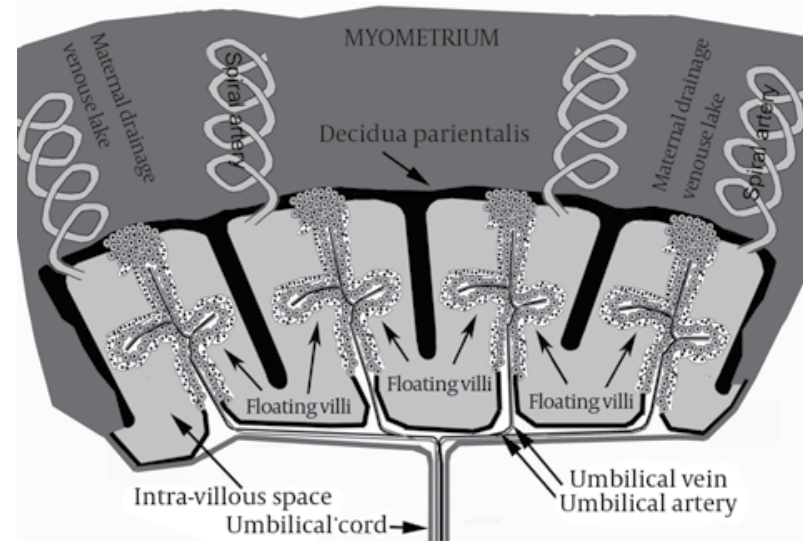

Figure 5. Ultra-Efficient Fetal-Maternal Nutrient Exchange or Hemochorial Placentation. hCG and hyperglycosylated hCG promoted villous placenta formation as indicated in figure 4 . hCG promotes growth or angiogenesis of uterine arteries to meet the growing placenta $(24,64,74,92,93,97,98)$. hCG also controls the growth of umbilical vasculature to meet the developing hemochorial placentation. All told, hCG and hyperglycosylated hCG function to build ultra-efficient nutrient exchange or hemochorial placentation.
hCG controls fetal growth during pregnancy. Fetal hCG receptor disappear prior to parturition so are not present in human infants. The fetus has been demonstrated to produce its own variant of hCG in the fetal liver and kidney (61). Control of fetal growth may be one of these most major functions of hCG.

The story does not end here, hCG receptor have been identified in maternal brain hippocampus, brain stem and brain hypothalamus. We do not understand brain function well enough to understand the function of hCG in human brain. Maybe there are some maternal brain adjustments associated with pregnancy? We do realize a likely symptom of the brain receptors in key locations in the brain, that is hyperemesis gravidarum or the cause of morning sickness or nausea and vomiting during pregnancy $(79,83,85)$. Let us consider hyperglycosylated hCG, that cytotrophoblast autocrine produced during pregnancy. Hyperglycosylated hCG is a form of hCG with large triantennary N-linked oligosaccharides (Figure 3) 
and hexasaccharide O-linked oligosaccharides $(42,43)$. It is our understanding that hyperglycosylated hCG exposes hCG's common structure with TGFß (23) and antagonizes a TGFß receptor on cytotrophoblast cells (15). The binding to TGFß receptor blocks apoptosis in cells (73), promotes cell growth and cell production of invasive enzymes, metalloproteinases and collagenases (99-104). Hyperglycosylated hCG is the principal form of hCG produced in early pregnancy because it drives implantation of pregnancy $(37,40)$, using the metalloproteinases and collagenases to digest the way of blastocyst/conceptus/ placenta as it invades feep into the uterus. By the end of the first trimester of pregnancy the placenta buries itself at approximately $1 / 3$ rd the thickness of the myometrium [108], having penetrated the decidual and the myometrium. Hyperglycosylated hCG drive placenta or cytotrophoblast cell growth during the course of pregnancy $(15,16,24,37,64,74,90,92,93,97,98)$, cytotrophoblast cells are continuously fused and differentiated to make syncytiotrophoblast cells under the control of hCG (90). Hyperglycosylated hCG may drive implantation of pregnancy $(37,40)$, yet unfortunately invasion-like processes are not always perfect. Ultra-efficient hemochorial placentation developed in humans to permit the evolution of the human brain $(18,65)$. Such demand for ultra-efficiency comes with valves and failures. As shown, inefficient pregnancy implantation is the cause of all spontaneous abortions or miscarriages of pregnancy, except for gross genetic abnormalities $(105,106)$. It is also the cause of biochemical pregnancies $(105,106)$. As now demonstrated, these are all due to deficient hyperglycosylated hCG (107). As shown, when hyperglycosylated hCG is less than $50 \%$ of total hCG at the time of implantation, a biochemical pregnancy or spontaneous abortion is the outcome (107) This study was quite absolute, 81 of 81 pregnancy with term outcome has a hyperglycosylated hCG of $>50 \%$ of total hCG (107). Hyperglycosylated hCG (<50\%) is seemingly a definitive test for pregnancy outcome on the day of pregnancy implantation. Hyperglycosylated hCG is also valuable during pregnancy in the detection of Down syndrome pregnancies. Hyperglycosylated hCG, the implantation driver, outperforms hCG and its free ßsubunit in detecting Down syndrome pregnancies (108,
109). Hyperglycosylated hCG is also useful in the prediction of preeclampsia or pregnancy induced hypertension in pregnancy (110). Preeclampsia or pregnancy induced hypertension result when hemochorial placentation fails to be instrumented correctly due to failure of complete placental invasion/implantation $(111,112)$.

\section{3. hCG and Hyperglycosylated hCG, the Potent Growth and Invasion Factors That Forced Human Evolution}

It is fascinating to examine how and why hCG and hyperglycosylated hCG evolved. They appeared to evolve as ultra-growth and invasion factors, that seemingly promoted placentation in primates to the extreme level needed to support the development of the human brain (113-115). It is these ultra-growth and invasion factors that drive human pregnancy or human life, and are abused by human cancers as described in this report, to drive them through deadly malignancy. That is why in this review's title we call hCG the centerpiece of life and death.

This section summarizes publications describing the role of hCG and hyperglycosylated hCG in human evolution $(18,65,116)$. The earliest primates, prosimian primates (i.e. lemurs) had small brains like earlier mammals, $0.07 \%$ of body weight (Table 4 ). They had small brains because these primates and earlier mammals used an ineffective placentation system, non-invasive epitheliochorial placentation. In this placentation system, maternal nutrients travelled across multiple layers of decidua, endometrial epithelium, chorionic epithelium and connective tissue to reach the fetal circulation or the umbilical veins. With evolution, the next level of primates, early simian primates (i.e. marmoset and monkey) CG (we call it CG rather than hCG, since this is not humans) and hyperglycosylated CG first evolved. A long with the evolution of these molecules came their functional product, hemochorial placentation, as described in section 2 of this review on human pregnancy $(15,16,37-39,65,68,73,87$, $88,94)$. Hemochorial placentation, or the maternal-fetal circulation interface, was much more efficient than epitheliochorial placentation, with nutrients only having to cross one cell thickness, syncytiotrophoblast cells, to cross between the maternal circulation and umbilical of

Table 4. Parallelisms Between Placental Implantation and Invasion Characteristics in Primates, Presence and Sugar Structure on Chorionic Gonadotropin (CG) or LH, and Relative Brain Masses.

\begin{tabular}{|c|c|c|c|c|c|}
\hline & Placentation & $\begin{array}{l}\text { Depth of Inva- } \\
\text { sion of Placenta }\end{array}$ & $\begin{array}{l}\text { Sugar Structures, Acidity } \\
\text { or pI }{ }^{\text {a }}\end{array}$ & $\begin{array}{l}\text { Brain Mass } \\
\text { (\% Body Weight) }\end{array}$ & First Appearance \\
\hline Humans & Hemochorial & 1/3rd myometrium & $\begin{array}{l}\text { CG, } 8 \text { oligosaccharides, } \\
\text { pI } 3.5\end{array}$ & 2.4 & 0.1 million years ago \\
\hline $\begin{array}{l}\text { Advanced simian } \\
\text { primates }\end{array}$ & Hemochorial & $\begin{array}{l}\text { 1/10th myome- } \\
\text { trium }\end{array}$ & $\begin{array}{l}\text { CG, } 6 \text { oligosaccharides, } \\
\text { pI } 4.9\end{array}$ & 0.74 & 20 million years ago \\
\hline $\begin{array}{l}\text { Early simian } \\
\text { primates }\end{array}$ & Hemochorial & $\begin{array}{l}\text { through decidua } \\
\text { only }\end{array}$ & $\begin{array}{l}\text { CG, } 5 \text { oligosaccharides, } \\
\text { pI } 6.3\end{array}$ & 0.17 & 37 million years ago \\
\hline $\begin{array}{l}\text { Prosimian pri- } \\
\text { mate }\end{array}$ & $\begin{array}{l}\text { Epitheliocho- } \\
\text { rial }\end{array}$ & no-invasion & $\begin{array}{l}\text { No CG produced, only LH } \\
\text { LH, } 3 \text { oligosaccharides, pI } 9.0\end{array}$ & 0.07 & 55 million years ago \\
\hline
\end{tabular}

${ }^{\mathrm{a}}$ Isoelectric Point 
fetal circulation. The story of CG and hyperglycosylated CG and evolution is how an ultra-efficient form of hCG evolved, capable of forming ultra-efficient hemochorial placentation that permitted the evolution of the human brain.

In 1980 Fiddes and Goodman (19) examined the DNA sequence for the ß-subunits of CG and LH in humans and primates. They showed that the evolution of CG from LH occurred in early simian primates by a single point deletion mutation in LH ß-subunit DNA at a base corresponding to LH amino acid residue 114, and read-through into the 3'-untranslated region of the molecule making and ß-subunit of 145 vs. 121 amino acids. In 2002 Maston and Ruvolo (117) investigated the DNA sequences of the $ß$ subunits of CG in 14 different primates and showed that the genes to make CG and its variants were not present in prosimian primates. They confirmed that CG evolved by the indicated deletion mutation with early simian primates.

While early simian primate LH had just $3 \mathrm{~N}$-linked oligosaccharides, the first or early simian primate CG and hyperglycosylated CG molecules had $3 \mathrm{~N}$-linked and $2 \mathrm{O}$ linked oligosaccharides or 5 oligosaccharides total, with the 2 O-linked oligosaccharides developing from the extended peptide sequence, the ß-subunit C-terminal peptide, deriving from the read through into the 3'-untranslated region of the LHß gene (Table 4).

Early simian primates evolved approximately 37 million year ago (Table 4). With the evolution of advanced simian primates, about 20 million ago (examples: orangutan and chimpanzee) came with further point mutations a form of CG and hyperglycosylated CG that had 3 $\mathrm{N}$-linked and 3 O-linked oligosaccharides or 6 oligosaccharides total (Table 4). With the evolution of humans, 0.1 millon year ago, and with multiple further point mutations came the evolution of human CG (hCG) and hyperglycosylated CG (hyperglycosylated hCG) having $4 \mathrm{~N}$-linked and 4 O-linked oligosaccharides or 8 oligosaccharides total. With the increasing numbers of oligosaccharides and their terminating sialic residues ( 2 per oligosaccharide) or acidic sugars, and with structures evolving with 3 oligosaccharides ( 6 sialic acid), 5 oligosaccharides total (10 sialic acid), to 6 oligosaccharides total (12 sialic acid) and on to 8 oligosaccharides total (16 sialic acid) came the evolution of a human CG with a greater and greater acidity. The acidity ranged from isoelectric point (pI) 9.0 with prosimian LH to pI 6.3 in early simian CG, to pI 4.8 in advanced simian CG and on to super-acidic pI 3.5 molecules in human CG $(18,65$, 117$119)$. CG is the most acidic glycoprotein made by humans. Evolution took hCG acidity to the extreme.

The metabolic clearance rate of circulating levels of CG advanced with evolution and acidity. As CG evolved with further oligosaccharides containing sialic acid, it very much lengthened the metabolic clearance rate or biological activity of CG and hyperglycosylated CG molecules $(117,120,121)$. As an example, at one extreme is LH [pI 9.0
(49)] with just $3 \mathrm{~N}$-linked oligosaccharides. This has a pI of 9.0 and a circulating half-life of 25 minutes (49). At the other extreme is regular human CG with 8 oligosaccharides terminating in sialic acid. These acidify hCG resulting in a molecule with a mean pI of 3.5, and a circulating half-life of 2160 minute (34). Effectively the extreme acidity of hCG extends its biological activity $2160 / 25$ or 86 -fold over LH.

Considering that LH has 3 oligosaccharides and a clearance rate, half-life of 25 minutes, and human CG has 8 oligosaccharides and a clearance rate half-life of 2160 minutes, a regression equation was found linking the number of oligosaccharides and the metabolic clearance rates of molecules. If clearance rate is $\mathrm{CR}$ and number of oligosaccharides is \#O then $\mathrm{CR}=2.4 \# \mathrm{O} \times 1.9$ ). It was calculated using this equation that while the clearance rate half-life of LH and human CG are 25 and 2160 minutes, that the clearance rate half-life of early simian primate CG was rougly 150 minutes and the clearance rate halflife of advanced simian primate CG was 360 minutes. As such, human CG is approximate 6-fold more potent that advanced primate CG, which is approximately 2.4 -fold more potent than early simian CG, which was approximately 6-fold more potent than $\mathrm{LH}$.

The size of the brain in mammals is related to the combination of body mass and the metabolic support of the developing offspring (112-118, 122-126). The larger brain seen in advanced primates and humans, correlates with disproportionately large energy demands by the developing fetuses [128-130]. Many studies support the concept that advanced primates and humans had to develop ultra-efficient placentation mechanisms to support the increasing nutritional demands of their embryonic brain (Table 4) (118, 119, 122-127).

Prosimian primates had an average mammalian brain, $0.07 \%$ of body mass (Table 4 ). In this species, epitheliochorial placentation was sufficient. Hemochorial placentation started with the evolution of CG in early simian primates. It was only with the appearance of CG and hyperglycosylated CG in early simian primates, that the signals to implant placentas inside the uterus (37-40), and to generate villous placenta $(18,65,116)$, to promote angiogenesis of uterine vasculature $(24,64,74,92,93,97$, 98 ) and development of the umbilical cord $(70,96)$ that hemochorial placentation happened $(65,116)$. Hemochorial placentation was primitive in early simian primates, placentas implanting only through the depth of the decidua, leading to a larger brain $0.17 \%$ of body mass (Table 4 ). It was with evolution and the development of more-acidic more-potent CG and hyperglycosylated CG in advance simian primates that hemochorial placentation went deeper to 1/10th of myometrial depth in advance simian primates (Table 4). Hemochorial placentation supported the development of a much larger brain in advance simian primates of $0.74 \%$ of body mass (Table 4 ).

With the evolution of humans and the multiple mutations needed to produce their super acidic-CG with 
2 additional oligosaccharides, one N-liked and one Olinked, hemochorial placentation took the molecule to the extreme. CG jumped in acidity from pI 4.8 to pI 3.5, this raised the metabolic clearance rate half-life from 360 minutes ( 6 hours) to 2160 minutes (36 hours). With this hemochorial placentation went deeper to $1 / 3$ rd the width of the myometrium (Table 4). Hemochorial placentation reached then the ultra-efficiency needed to support a human brain, $2.4 \%$ of body mass.

Nutrition transfer and placentation was taken to the extreme in the humans. Human CG is extremely acidic with 4 O-linked and $4 \mathrm{~N}$-linked oligosaccharides with a circulating half-time of 2160 minutes. This causes invasion through the decidua to one third the thickness of the myometrium and to the ultra-efficient placentation that is needed to support the nutritional transfer necessary for a brain of $2.4 \%$ body mass or 3 fold greater than that of advanced simians, to develop (113-115,127). Considering the relationship between regular CG, hyperglycosylated CG and hemochorial placentation, and between advancing acidity of CG and advancing invasion and angiogenesis, it would be appropriate to claim that the evolution of CG in early simians started primates on the evolution path to advanced brains, or is at the root of the evolution of humans $(18,65,116)$.

It is with this evolution story that human ultra efficientCG and ultra efficient -hyperglycosylated CG were created. Unfortunately, human cancers abuse these ultra-efficient growth, angiogenic and invasion factors to drive malignancy (see Section 5, hCG and cancer). This should be considered an artifact of human evolution.

\section{Sulfated hCG a Key Hormone Produced by the Pituitary Gland}

A fifth variant of hCG is produced by pituitary gonadotrope cells during the routine menstrual cycle in women, this is sulfated hCG $(31,128)$. It is wrong to say that hCG is strictly a pregnancy hormone, it is normally produced in pregnancy and in normal women during the menstrual cycle. Non-pregnancy production of hCG has been a major source of confusion in the medical field. Research using a sensitive total or intact hCG assay shows that sulfated hCG is secreted during the length of the menstrual cycle (31), analogous to the normal secretion pattern of LH. Sulfated hCG and LH both bind a joint receptor, the hCG/LH receptor. Pituitary hCG contains a mixture of sulfated and sialylated oligosaccharides (Figure 2) (9). Research shows that in $\mathbf{2 7 7}$ menstrual cycles at the time of the mid-cycle LH peak sulfated hCG production averages $1.54 \pm 0.90 \mathrm{mIU} / \mathrm{mL}$ (129). Sulfated hCG copies LH actions in promoting progesterone production by corpus luteal cells, androstenedione production by theca cells, and in enhancing ovulation. LH, FSH and sulfated hCG, produced by gonadotrope cells, all have key functions during the menstrual cycle $(15,31,128,129)$.

Why we ask does the pituitary produce sulfated hCG to supplement LH and to help LH complete the LH job? Sulfated $\alpha$-subunit is produced in excess by the pituitary. A single $\alpha$-subunit pairs with hCG, LH, follicle stimulating hormone (FSH) and thyroid stimulating hormone (TSH). Gonadotropin releasing hormone (GnRH) is made by the hypothalamus of the brain and through the hypothalamic-hypophyseal portal circulation promotes the ß-subunits of LH and FSH. As illustrated in Figure 6, a single LHß gene resides directly next to 8 tandem genes coding for hCGß on chromosome 19 . Since such a tiny amount of hCG are produced by the pituitary it is thought that hCGß is expressed as consequence of large pulses of GnRH acting on the LHß gene. Clearly, the large pulses of GnRH cannot avoid promoting hCGß (Figure 6).

It has been calculated that sulfated hCG (0.01 - $9 \mathrm{mIU} /$ $\mathrm{ml}$ ) is produced at approximately $1 / 50$ th the serum concentration of LH $(1-159 \mathrm{mIU} / \mathrm{ml})(9,31,129)$. Yet sulfated

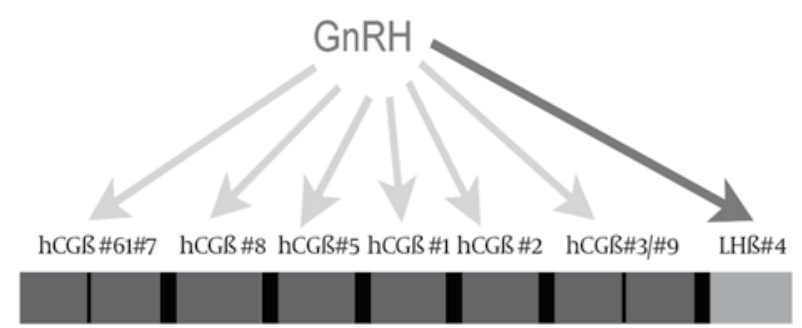

Figure 6. Mechanism of Action of GnRH in Production of Sulfated Pituitary hCG. Pulses of GnRH Promote LHß Gene, but cannot avoid stimulating associated hCGß genes.

hCG has 50 times the biological activity of LH per mole of hormone released in blood (sulfated hCG is less potent than regaular hCG, which is 86 -fold more potent than LH) (9). Considering the 2 calculations together, $1 / 50$ th the concentration and 50-fold greater biological activity, sulfated hCG and LH seemingly have equal functions. Equal functions in promoting androstenedione production, promoting progesterone production and promoting ovulation. No longer can the claim be made that LH promotes ovulation, it is LH and sulfated hCG that jointly promote ovulation. Some cases have low LH at ovulation. Without measuring sulfated hCG and LH together a true assessment of ovulation problems cannot be obtained. Sulfated hCG at $1 / 50$ th the concentration of LH is barely detectable during the menstrual cycle. At the time of the LH peak, however, hCG level averaged $1.54 \pm 0.90$ $\mathrm{mIU} / \mathrm{mL}$ (129), or was mostly detectable by modern total hCG immunoassays. In menopause, with the absence of sex steroid feedback (estradiol and progesterone) to the hypothalamus, GnRH pulses from the hypothalamus become maximal. The result is promotion of excess LH, hCG and FSH production by gonadotrope cell due to extreme GnRH pulses. Serum LH increases from, 1-90 mIU/mL to $>100 \mathrm{mIU} / \mathrm{mL}$ in menopause, serum FSH increases from 1-29 $\mathrm{mIU} / \mathrm{ml}$ to $30-200 \mathrm{mIU} / \mathrm{ml}$ in menopause, and serum hCG from $<0.01-9 \mathrm{mIU} / \mathrm{ml}$ to $2-39 \mathrm{mIU} / \mathrm{ml}$ in menopause. All told, normal sulfated hCG is very detectable in a menopausal woman $(9,31,128-131)$. Perimenopause is the 
stage prior to menopause marked by oligomenorrhea or irregular menstrual periods. Just as perimenopause is marked by the start of raised LH and FSH production, it is also marked by bnormal detectable hCG levels. Seemingly, exceptional women can achieve pregnancy up to 60 years age. This is very rare. In general, women $40-55$ years age are likely to be in perimenopause, and those $>55$ years age are surly in menopause (132). As reported, the range of hCG detection in non-pregnant menopausal women, $>55$ years age, is $<2$ to $13.1 \mathrm{mIU} / \mathrm{ml}$, in non-pregnant menstrual women $18-40$ years age is $<2$ to $4.6 \mathrm{mIU} / \mathrm{ml}$, and potential perimenopause women is $<2$ to $7.7 \mathrm{mIU} / \mathrm{ml}$ (132). In the USA hCG Reference Service experience, hCG levels as high as $29 \mathrm{mIU} / \mathrm{ml}$, median $7.2 \mathrm{mIU} / \mathrm{ml}$ are detected in perimenopause and as high as $33 \mathrm{mIU} / \mathrm{ml}$, median $8.0 \mathrm{mIU} / \mathrm{ml}$ are detected in menopause. Higher hCG levels have been recorded, as high as $39 \mathrm{mIU} / \mathrm{ml}$, in women having oophorectomy or thrown into amenorrhea and menopause.

Most medical practices and hospitals throughout the world check women in an hCG test prior to the use of certain drugs, certain invasive procedures, and always prior to surgery. No care is given regarding women in perimenopause or menopause who may be naturally producing sulfated pituitary hCG. Unfortunately, when these women show positive for hCG it raises a needless alarm amongst doctors, leading to cancellation of surgery or other procedures. Physicians check these women first for the fetal sac of pregnancy by ultrasound, then after excluding clinical pregnancy they consider ectopic pregnancy. I have published dozens of times in journal ranging from New England Journal of Medicine to Clinical Chemistry $(130,131)$ that a positive hCG test in a woman over 45 is normal and should not be a concern. It is easy to prove that hCG production in a woman over 45 is pituitary hCG and very normal. Place a woman on a high estrogen contraceptive pill (Ortho-Novum, $0.035 \mathrm{mg}$ ethinyl estradiol) for 3 weeks, if her hCG then becomes undetectable, it is pituitary hCG.

Gronowowski et al. (133), showed that measurement of FSH levels is a powerful indicator of pituitary sulfated hCG (FSH >30 mIU/ml). The USA hCG Reference Service started using FSH as a confirmation of pituitary sulfated hCG about one year ago. As found, all menopausal cases tested since we started measuring FSH, are highly positive for FSH (61-190 mIU/ml). The high $190 \mathrm{mIU} / \mathrm{ml} \mathrm{FSH}$ correlated with the case producing the highest pituitary sulfated hCG, $39 \mathrm{mIU} / \mathrm{ml}$. We very much support the use of FSH testing to confirm pituitary hCG. Once a woman is diagnosed as producing pituitary sulfated hCG, what do you do next? The answer is "nothing," it is normal it is natural, you need to completely ignore it.

5. Hyperglycosylated hCG, hCG Free B, and Hyperglycosylated Free $\boldsymbol{B}$, the Potent Growth and Invasion Factors Abused by Human Malignancies
The preceding sections describe the key roles hyperglycosylated hCG has in commanding pregnancy. As describe in Section 3, this extreme growth and invasion factor was generated to drive human evolution. While it is very acceptable that this extreme factor goes on to drive human pregnancy, it is not acceptable that this factor is abused to drive all advanced human malignancies. Hyperglycosylated hCG and its analogues are seemingly selected as potent TGFß antagonist (15). Evolutionarily selected to use this potent invasive pathway to drive human malignancies $(13,18,65)$. Here we carefully examine what we now know about these molecules and how they seemingly drive all human cancers. Multiple investigators have noticed a common molecular evolutionary origin of TGFß and hCGß $(134,135)$. In 1994 Lapthorn and colleagues (23) found a rare four peptide linked cystine knot structure within the 3 dimensional structure of hCGß. This cystine knot structure is common to hCGß and TGFß. As found by Butler and colleagues in 1990 (13), hCG free $ß$, a proven cancer promoter $(13,15,17,136-160)$, acts on cancer by antagonizing the TGFß receptor on cancer cells. As shown recently, hCG does not express these TGFß binding structures and does not function by this pathway (15), but hyperglycosylated hCG (choriocarcinoma cancer promoter $(16,37))$, and another cancer promoter, hyperglycosylated free $\beta$, both are interchangeable with hCG free $\beta$ in promoting growth of cancer cells. Indicating that all 3 interchangeable promoters, hCG free $ß$, hyperglycosylated hCG and hyperglycosylated free $\beta$ function by antagonizing a TGFß receptor (15). The antagonism of a TGFß receptor blocks apoptosis in cancer cells $(13,73,139,140,148)$, promotes cancer cell growth and cell production of invasive enzymes, metalloproteinases and collagenases (13, 99-104, 137, 139, 140, 145, 148, $150,153)$. History identifies two hCG-related cancer markers, hCG free $ß$ and hyperglycosylated hCG free $ß$. Many researchers noted through the years that the hCG free $\beta$ produced by cancer cell lines and present in cancer patient serum was unduly large $(17,158)$, larger than hCG ßsubunit in size. In 2006 Valmu and colleagues (43) used mass spectrometry to show that the large free $\beta$ is actually hyperglycosylated free $\beta$, resembling the $\beta$-subunit of hyperglycosylated hCG. Recently, it has been shown that cancers invariably produce different proportions of hCG free $ß$ and hyperglycosylated free $ß$ (15). It is thought that cancer cell free $\beta$ is invariably glycosylated containing $0-100 \%$ hyperglycosylated free $ß$. Is it necessary to keep calling these free $ß$ and hyperglycosylated free $ß$. I think not, maybe they booth should be called vg (variably glycosylated) hCG free ß (vg-hCG free ß). Choriocarcinoma and germ cell malignancies characteristically produce cytotrophoblast cells and express hyperglycosylated hCG $(15,37)$. It is my understanding that hyperglycosylated hCG drives all these malignancies, by the same TGFß antagonizing pathways that hyperglycosylated hCG used to implant pregnancies. Hyperglycosylated hCG drives all stages of these malignancies, early and advanced $(161,162)$. As demonstrate, when these malignancies are 
transplanted into nude mice they grow and metastasize rapidly. When the nude mice are given injections of B152 monoclonal antibody to hyperglycosylated hCG all growth and malignancy comes to a complete halt. Effectively, blockage of hyperglycosylated hCG cures or blunts these diseases $(16,73)$. We call these cancers Type 1 cancers, or those totally dependent on hyperglycosylated hCG. Starting in the early 1970s with the introduction of the hCGß radioimmunoassay (33) scientist started showing that all cancer cell lines produced an hCGß immunoactive molecule, and hCGß immunoreactive molecules were detected in cancer patient serum and urine. In 1978 Franchimont and colleagues (21), and in 1980 Rosen and collegues demonstrated an hCG free $ß$ produced by a cancer cell line. In 1983 I demonstrated hCG free ß-subunit in two cervical cancer cell lines and then found an hCG free $ß$ in corresponding cancer cases serum and urine (17). As found at that time, the hCG free $\beta$ was unduly large, recently shown to be hyperglycosylated free $ß$. We now call all of these cancer molecules vg-hCG free $ß$.

Reports by the hundreds continued showing that cancer cell lines produced vg-hCG free $ß$ or an hCGß-immunoreactive molecule (136-160). Between 1992 and 1996 Acevedo and colleagues $(4,136,163)$ and Regelson and colleagues (156)showed using flow cytometry and immunoassay methods that all cancers made vg-hCG free $ß$. Interestingly, in a large compilation of studies, shown in Table 5, vg-hCG free $ß$ and its urine degradation product $ß$ core fragment can only be detected in 30\% (serum vg-hCG free $ß$ ) and $48 \%$ (urine ß-core fragment) of cancer cases. How can we explain this discrepancy, $30 \%$ and $48 \%$ versus $100 \%$ ? The problem is that vg-hCG free $\beta$ is normally very rapidly cleared from the circulation (34). When one considers that monocytes, leukocytes and macrophages accumulate close to a malignancy, cleaving the vg-hCG so that it is nicked and has a cleaved C-terminal peptide, then clearance from the circulation may be reduced to seconds (45). As a result, these tumor vg-hCG free ß molecules and their degradation product ß-core fragment, may only rarely be detectable in serum or urine. Considering the detection of $30 \%$ and $48 \%$ of cases, seemingly the extreme cases, these finding are consistent with all cancers producing vg-hCG free $ß$.

In recent years it has been demonstrated that vg-hCG free $\beta$ has key roles in advanced malignancies, promotes cancer growth and malignancy $(13,137,139,140,145$, $148,150,153)$. Acting by antagonizing the cancer cell TGFß receptor (13), vg-hCG free $ß$ seemingly blocks cell apoptosis $(13,139,140,148)$. Much more research has been completed on how the interchangeable marker hyperglycosylated hCG, antagonizes a TGFß receptor and promotes implantation of pregnancy (15) using metalloproteinases and collagenases (99-104). It is inferred that TGFß antagonism in cancer cell similarly enhanced metalloproteinases and collagenase production, leading to cell invasion or metastases. Today we know that vg-hCG free $ß$ enhancement of all cancers is limited to advanced malignancies only. It appears that cancers advance using alternative growth and invasion mechanisms. When cancer advance mechanism are found to express the hCGß genes, 8 tandem genes, on chromosome 19. With the expression of vg-hCG free $\beta$ a new efficient pathway is found by the cancer cell to promote cancer growth and invasion, the vg-hCG : TGFß antagonism pathway. It is clear from the vaccine studies, described below, that this becomes the dominant or solitary cancer growth and invasion pathways.

How are all these cancer discoveries reflecting on cancer treatment? Three companies, Celldex, CG Therapeutics and MCI BioPharma Inc. started in 2000 testing a a synthetic hCGß vaccine in treating advanced cancer cases (164-169). Results are very exciting, with the finding that hCGß vaccines are considerably extending lives of advanced cancer patients. For example, examining the clinical trial with hCGß vaccine and colorectal cancers (168), the average survival of those with optimal antibody response was 45 weeks, compared to just 24 weeks in those without optimal antibody response ( $p=0.0003)$. This demonstrates that hCG antibodies can double longevity. Sumilar results have been report with prostate cancer, lung cancer and breast cancer. We ask, could the discovery of vg-hCG free $ß$ be the new cancer cure?

Table 5. Use of Serum Free ß-Subunit (vg-hCG Free ß ) and Urine ß-Core Fragment as Tumor Markers for Detection of Malignancies. All averages are determined by combining total positive cases from multiple reports (136-160).

\begin{tabular}{|c|c|c|c|c|}
\hline & \multicolumn{2}{|c|}{ hCGß as a Tumor Marker } & \multicolumn{2}{|c|}{ ß-Core Fragment as a Tumor Marker } \\
\hline & Cases, No. & $\begin{array}{l}\text { Serum hCGß } \\
\text { (>3 pmol/L), \% }\end{array}$ & Cases, No. & $\begin{array}{l}\text { Urine ß-Core Fragment } \\
(>3 \mathrm{pmol} / \mathrm{L}), \%\end{array}$ \\
\hline Bladder cancer & 170 & 35 & 102 & 48 \\
\hline Cervical cancer & 60 & 37 & 410 & 48 \\
\hline Colorectal cancer & 436 & 17 & & \\
\hline Endometrial cancer & 55 & 33 & 157 & 47 \\
\hline Lung cancer & 243 & 18 & 122 & 45 \\
\hline Ovarian cancer & 150 & 38 & 207 & 66 \\
\hline Pancreatic cancer & - & - & 29 & 55 \\
\hline Vulvar & 64 & 41 & - & - \\
\hline TOTAL & 1164 & Mean 30 & 1027 & Mean 48 \\
\hline
\end{tabular}


The company Omnimmune Corp. is proposing to generate human antibodies to hyperglycosylated hCG/hCGß and to hCGß. These antibodies should generate a higher success rate than the vaccine since they do not require the limitation of having appropriate immunity, which a person undergoing multiple cancer chemotherapies may not have. If you consider that a vaccine can raise human survival 2-fold in advanced malignancies then what may be on the horizon using administered antibodies, maybe more than 2-fold improvement of survival for advance cancer cases. Raising human advanced cancer survival more than 2-fold brings cancer treatment into a new horizon.

I consider general malignancies as type 2 malignancies in that vg-hCG free $\beta$ is only critical to advanced malignancies. I believe that the hCG and cancer story will bring a promising future to cancer therapy. Please remember, this just an artifact to human evolution. I hope that in the near future that hCGß antibody cancer therapy may bring a cure to type 1 malignancies, and a great improvement in therapy for type 2 malignancies.

\section{Acknowledgments}

None declared.

\section{Financial Disclosure}

None declared.

\section{Funding/Support}

None declared.

\section{References}

1. Aschner B. About the functioning the pituitary. pflug Arch Eur J Phy. 1912;146(1):1-146.

2. Hirose T. Experimentalle histologische studie zur genese corpus luteum. Mitt Med Fakultd.1919(23):63-70.

3. Aschheim S, Zondek B. The hormone of the anterior pituitary: test for detection of the object-hormone. Klin Wochenschr. 1927;6:248-52.

4. Acevedo HF, Hartsock RJ. Metastatic phenotype correlates with high expression of membrane-associated complete beta-human chorionic gonadotropin in vivo. Cancer.1996;78(11):2388-99.

5. Amr S, Rosa C, Wehmann R, Birken S, Nisula B. Unusual molecular forms of hCG in gestational trophoblastic neoplasia. Ann Endocrinol (Paris). 1984;45(4-5):321-6.

6. Aono T, Goldstein DP, Taymor ML, Dolch K. A radioimmunoassay method for human pituitary luteinizing hormone (LH) and human chorionic gonadotropic (HCG) using 125-I-labeled LH. Am J Obstet Gynecol.1967;98(7):996-1001.

7. Ascoli M, Segaloff DL. On the structure of the luteinizing hormone/chorionic gonadotropin receptor. Endocr Rev. 1989;10(1):27-44.

8. Birken S, Berger P, Bidart JM, Weber M, Bristow A, Norman R, et al. Preparation and characterization of new WHO reference reagents for human chorionic gonadotropin and metabolites. Clin Chem. 2003;49(1):144-54

9. Birken S, Maydelman Y, Gawinowicz MA, Pound A, Liu Y, Hartree AS. Isolation and characterization of human pituitary chorionic gonadotropin. Endocrinology. 1996;137(4):1402-11.

10. Blithe DL, Nisula BC. Variations in the oligosaccharides on free and combined alpha-subunits of human choriogonadotropin in pregnancy. Endocrinology.1985;117(5):2218-28.

11. Bogart MH, Pandian MR, Jones OW. Abnormal maternal serum chorionic gonadotropin levels in pregnancies with fetal chromosome abnormalities. Prenat Diagn. 1987;7(9):623-30.

12. Boorstein WR, Vamvakopoulos NC, Fiddes JC. Human chorionic gonadotropin [beta]-subunit is encoded by at least eight genes arranged in tandem and inverted pairs. Nature. [10.1038/300419a0].1982;300(5891):419-22.

13. Butler SA, Ikram MS, Mathieu S, Iles RK. The increase in bladder carcinoma cell population induced by the free beta subunit of human chorionic gonadotrophin is a result of an anti-apoptosis effect and not cell proliferation. Br J Cancer. 2000;82(9):1553-6.

14. Cole LA. The O-linked oligosaccharide structures are striking different on pregnancy and choriocarcinoma HCG. J Clin Endocrinol Metab.1987;65(4):811-3.

15. Cole LA, Butler S. HyperglycosylatedhCG, hCGß and HyperglycosylatedhCGß: Interchangeable Cancer Promoters. Mol Cell Endocrinol 2011.

16. Cole LA, Dai D, Butler SA, Leslie KK, Kohorn EI. Gestational trophoblastic diseases: 1. Pathophysiology of hyperglycosylated hCG. Gynecol Oncol. 2006;102(2):145-50.

17. Cole LA, Hartle RJ, Laferla JJ, Ruddon RW. Detection of the free beta subunit of human chorionic gonadotropin (HCG) in cultures of normal and malignant trophoblast cells, pregnancy sera, and sera of patients with choriocarcinoma. Endocrinology. 1983;113(3):1176-8.

18. Cole LA, Khanlian SA, Kohorn EI. Evolution of the human brain, chorionic gonadotropin and hemochorial implantation of the placenta: insights into origins of pregnancy failures, preeclampsia and choriocarcinoma. J Reprod Med. 2008;53(8):549-57.

19. Fiddes IC, Goodman HM. The cDNA for the beta-subunit of human chorionic gonadotropin suggests evolution of a gene by readthrough into the 3'-untranslated region. Nature. 1980;286(5774):684-7.

20. Fiddes JC, Goodman HM. The gene encoding the common alpha subunit of the four human glycoprotein hormones. J Mol Appl Genet. 1981;1(1):3-18.

21. Franchimont P, Reuter A, Gaspard U. Ectopic production of human chorionic gonadotropin and its alpha- and beta-subunits. Curr Top Exp Endocrinol.1978;3:201-16.

22. Hussa R, En H. A two-site immunometric assay in evaluation of low levels of serum hCG. Am Clin Prod Rev.1984;3(12):12-7.

23. Lapthorn AJ, Harris DC, Littlejohn A, Lustbader JW, Canfield RE, Machin KJ, et al. Crystal structure of human chorionic gonadotropin. Nature.1994;369(6480):455-61.

24. Lei ZM, Reshef E, Rao V. The expression of human chorionic gonadotropin/luteinizing hormone receptors in human endometrial and myometrial blood vessels. J Clin Endocrinol Metab. 1992;75(2):651-9.

25. McFarland KC, Sprengel R, Phillips HS, Kohler M, Rosemblit N, Nikolics K, et al. Lutropin-choriogonadotropin receptor: an unusual member of the $\mathrm{G}$ protein-coupled receptor family. Science. 1989;245(4917):494-9.

26. Mizuochi T, Nishimura R, Derappe C, Taniguchi T, Hamamoto $\mathrm{T}$, Mochizuki M, et al. Structures of the asparagine-linked sugar chains of human chorionic gonadotropin produced in choriocarcinoma. Appearance of triantennary sugar chains and unique biantennary sugar chains. J Biol Chem.1983;258(23):141269.

27. Morgan FJ, Birken S, Canfield R. The amino acid sequence of human chorionic gonadotropin. The alpha subunit and beta subunit.J Biol Chem. 1975;250(13):5247.

28. Nishimura R, Ide K, Utsunomiya T, Kitajima T, Yuki Y, Mochizuki M. Fragmentation of the beta-subunit of human chorionic gonadotropin produced by choriocarcinoma. Endocrinology. 1988;123(1):420-5.

29. Policastro PF, Daniels-McQueen S, Carle G, Boime I. A map of the hCG beta-LH beta gene cluster. J Biol Chem. 1986;261(13):5907-16.

30. O'Connor JF, Ellish N, Kakuma T, Schlatterer J, Kovalevskaya G. Differential urinary gonadotrophin profiles in early pregnancy and early pregnancy loss. Prenat Diagn. 1998;18(12):1232-40.

31. Odell W, Griffin J. Pulsatile secretion of human chorionic gonad- 
otropin in normal adults. New Engl J Med.1987;317(27):1688-91.

32. Swaminathan N, Bahl OP. Dissociation and recombination of the subunits of human chorionic gonadotropin. Biochem Biophys Res Commun.1970;40(2):422-7.

33. Vaitukaitis JL, Braunstein GD, Ross GT. A radioimmunoassay which specifically measures human chorionic gonadotropin in the presence of human luteinizing hormone. Am J Obstet Gynecol.1972;113(6):751-8.

34. Wehmann RE, Nisula BC. Metabolic and renal clearance rates of purified human chorionic gonadotropin. J Clin Invest. 1981;68(1):18494.

35. Wide L, Gemzell CA. An immunological pregnancy test. Acta Endocrinol (Copenh). 1960;35:261-7.

36. Zondek B, Aschheim S. The zondek-ascheim pregnancy test. Can Med Assoc J. 1930;22:251-3.

37. Cole LA, Khanlian SA, Riley JM, Butler SA. Hyperglycosylated hCG in gestational implantation and in choriocarcinoma and testicular germ cell malignancy tumorigenesis. J Reprod Med. 2006;51(11):919-29.

38. Guibourdenche J, Handschuh K, Tsatsaris V, Gerbaud P, Leguy M, Muller F, et al. Hyperglycosylated hCG is a marker of early human trophoblast invasion. J Clin Endocrinol Metab. 2010;95(10):E240.

39. Handschuh K, Guibourdenche J, Tsatsaris V, Guesnon M, Laurendeau I, Evain-Brion D, et al. Human chorionic gonadotropin produced by the invasive trophoblast but not the villous trophoblast promotes cell invasion and is down-regulated by peroxisome proliferator-activated receptor-gamma. Endocrinology. 2007;148(10):5011-9.

40. Sasaki Y, Ladner DG, Cole LA. Hyperglycosylated human chorionic gonadotropin and the source of pregnancy failures. Fertil Steril. 2008;89(6):1781-6.

41. Schmitt EJ, Barros CM, Fields PA, Fields MJ, Diaz T, Kluge JM, et al. A cellular and endocrine characterization of the original and induced corpus luteum after administration of a gonadotropinreleasing hormone agonist or human chorionic gonadotropin on day five of the estrous cycle. J Anim Sci.1996;74(8):1915-29.

42. Elliott MM, Kardana A, Lustbader JW, Cole LA. Carbohydrate and peptide structure of the alpha- and beta-subunits of human chorionic gonadotropin from normal and aberrant pregnancy and choriocarcinoma. Endocrine. 1997;7(1):15-32.

43. Valmu L, Alfthan H, Hotakainen K, Birken S, Stenman UH. Sitespecific glycan analysis of human chorionic gonadotropin beta-subunit from malignancies and pregnancy by liquid chromatography-electrospray mass spectrometry. Glycobiology. 2006;16(12):1207-18.

44. Sutton JM. Charge variants in serum and urine hCG. Clin Chim Acta. 2004;341(1-2):199-203.

45. Cole LA, Kardana A, Andrade-Gordon P, Gawinowicz MA, Morris JC, Bergert ER, et al. The heterogeneity of human chorionic gonadotropin (hCG). III. The occurrence and biologica and immunological activities of nicked hCG. Endocrinology. 1991;129(3):1559-67.

46. Cole LA, Kardana A, Park SY, Braunstein GD. The deactivation of hCG by nicking and dissociation. J Clin Endocrinol Metab. 1993;76(3):704-10.

47. Kardana A, Cole LA. Human chorionic gonadotropin beta-subunit nicking enzymes in pregnancy and cancer patient serum. J Clin Endocrinol Metab. 1994;79(3):761-7.

48. Nisula BC, Blithe DL, Akar A, Lefort G, Wehmann RE. Metabolic fate of human choriogonadotropin. J Steroid Biochem. 1989;33(4B):733-7.

49. Veldhuis JD, Fraioli F, Rogol AD, Dufau ML. Metabolic clearance of biologically active luteinizing hormone in man. J Clin Invest. 1986;77(4):1122-8.

50. Cole LA, DuToit S, Higgins TN. Total hCG tests. Clin Chim Acta. 2011;412(23-24):2216-22.

51. Cole LA, Sutton JM, Higgins TN, Cembrowski GS. Between-method variation in human chorionic gonadotropin test results. Clin Chem. 2004;50(5):874-82.

52. Cole LA. hCG, five independent molecules. Clin Chim Acta. 2011.

53. Cole LA. Individual deviations in human chorionic gonadotropin concentrations during pregnancy. Am J Obstet Gynecol.
2011;204(4):349 e1-7.

54. Cole LA, Khanlian SA, Sutton JM, Davies S, Stephens ND. Hyperglycosylated hCG (invasive trophoblast antigen, ITA) a key antigen for early pregnancy detection. Clin Biochem. 2003;36(8):647-55.

55. Cole LA. Human chorionic gonadotropin (hCG) and hyperglycosylated hCG: the mediators that control human pregnancy. Expert Rev Obstet Gynecol. 2011;6(3):273-83.

56. Madsen BW. Spare receptors. Clin Exp Pharmacol Physiol. 1979;6(6):713-4.

57. Marunaka Y, Niisato N, Miyazaki H. New concept of spare receptors and effectors. J Membr Biol. 2005;203(1):31-9.

58. Siebers JW, Wuttke W, Engel W. HCG-binding capacity of the rat ovary during pregnancy. Acta Endocrinol (Copenh). 1977;86(1):1739.

59. Han SW, Lei ZM, Rao CV. Homologous down-regulation of luteinizing hormone/chorionic gonadotropin receptors by increasing the degradation of receptor transcripts in human uterine endometrial stromal cells. Biol Reprod.1997;57(1):158-64.

60. Rao CV, Sanfilippo J. New understanding in the biochemistry of implantation: Potential direct roles of luteinizing hormone and human chorionic gonadotropin. The Endocrinologist. 1997;7(2):107.

61. Abdallah MA, Lei ZM, Li X, Greenwold N, Nakajima ST, Jauniaux E, et al. Human fetal nongonadal tissues contain human chorionic gonadotropin/luteinizing hormone receptors. J Clin Endocrinol Metab. 2004;89(2):952-6.

62. Akoum A, Metz CN, Morin M. Marked increase in macrophage migration inhibitory factor synthesis and secretion in human endometrial cells in response to human chorionic gonadotropin hormone. J Clin Endocrinol Metab. 2005;90(5):2904-10.

63. Azuma K, Calderon I, Besanko M, MacLachlan V, Healy DL. Is the luteo-placental shift a myth? Analysis of low progesterone levels in successful art pregnancies. J Clin Endocrinol Metab. 1993;77(1):195-8.

64. Berndt S, Blacher S, Perrier d'Hauterive S, Thiry M, Tsampalas $\mathrm{M}, \mathrm{Cruz} \mathrm{A}$, et al. Chorionic gonadotropin stimulation of angiogenesis and pericyte recruitment. J Clin Endocrinol Metab. 2009;94(11):4567-74.

65. Cole LA. hCG and hyperglycosylated hCG in the establishment and evolution of hemochorial placentation. J Reprod Immunol. 2009;82(2):112-8.

66. Doheny HC, Houlihan DD, Ravikumar N, Smith TJ, Morrison JJ. Human chorionic gonadotrophin relaxation of human pregnant myometrium and activation of the BKCa channel. J Clin Endocrinol Metab. 2003;88(9):4310-5.

67. Duncan WC, Rodger FE, Illingworth PJ. The human corpus luteum: reduction in macrophages during simulated maternal recognition of pregnancy. Hum Reprod.1998;13(9):2435-42.

68. Eblen A, Bao S, Lei ZM, Nakajima ST, Rao CV. The presence of functional luteinizing hormone/chorionic gonadotropin receptors in human sperm. J Clin Endocrinol Metab. 2001;86(6):2643-8.

69. Edelstam G, Karlsson C, Westgren M, Lowbeer C, Swahn ML Human chorionic gonadatropin (hCG) during third trimester pregnancy. Scand J Clin Lab Invest. 2007;67(5):519-25.

70. Eta E, Ambrus G, Rao CV. Direct regulation of human myometria contractions by human chorionic gonadotropin. J Clin Endocrinol Metab. 1994;79(6):1582-6.

71. Gawronska B, Paukku T, Huhtaniemi I, Wasowicz G, Ziecik AJ. Oestrogen-dependent expression of LH/hCG receptors in pig Fallopian tube and their role in relaxation of the oviduct. J Reprod Fertil.1999;115(2):293-301.

72. Goldsmith PC, McGregor WG, Raymoure WJ, Kuhn RW, Jaffe RB. Cellular localization of chorionic gonadotropin in human fetal kidney and liver. J Clin Endocrinol Metab. 1983;57(3):654-61.

73. Hamada AL, Nakabayashi K, Sato A, Kiyoshi K, Takamatsu Y, Laoag-Fernandez JB, et al. Transfection of antisense chorionic gonadotropin beta gene into choriocarcinoma cells suppresses the cell proliferation and induces apoptosis. J Clin Endocrinol Metab. 2005;90(8):4873-9.

74. Herr F, Baal N, Reisinger K, Lorenz A, McKinnon T, Preissner KT, et al. HCG in the regulation of placental angiogenesis. Results of an in vitro study. Placenta. 2007;28 Suppl A:S85-93. 
75. Hirose T. Exogenous stimulation of corpus luteum formation in the rabbit: influence of extracts of human placenta, decidua, fetus, hydatid mole, and corpus luteum on the rabbit gonad. JJpn Gynecol Soc. 1920;16:1055.

76. Lei ZM, Rao CV, Kornyei JL, Licht P, Hiatt ES. Novel expression of human chorionic gonadotropin/luteinizing hormone receptor gene in brain. Endocrinology.1993;132(5):2262-70.

77. Matsuura T, Sugimura M, Iwaki T, Ohashi R, Kanayama N, Nishihira J. Anti-macrophage inhibitory factor antibody inhibits PMSG-hCG-induced follicular growth and ovulation in mice. $J$ Assist Reprod Genet. 2002;19(12):591-5.

78. Mayerhofer A, Fritz S, Grunert R, Sanders SL, Duffy DM, Ojeda SR, et al. D1-Receptor, DARPP-32, and PP-1 in the primate corpus luteum and luteinized granulosa cells: evidence for phosphorylation of DARPP-32 by dopamine and human chorionic gonadotropin. J Clin Endocrinol Metab. 2000;85(12):4750-7.

79. Rao CV. Chapter 11: Paradigm shift on the targets of hCG actions. In Human chorionic gonadotropin ( $h C G$ ) ed. Cole LA E, Oxford UK, editor.; 2010.

80. Perrier d'Hauterive S, Berndt S, Tsampalas M, Charlet-Renard C, Dubois M, Bourgain C, et al. Dialogue between blastocyst hCG and endometrial LH/hCG receptor: which role in implantation? Gynecol Obstet Invest. 2007;64(3):156-60.

81. Pierce JG, Parsons TF. Glycoprotein hormones: structure and function. Annu Rev Biochem. 1981;50:465-95.

82. Rao CV. Differential properties of human chorionic gonadotrophin and human luteinizing hormone binding to plasma membranes of bovine corpora lutea. Acta Endocrinol (Copenh). 1979;90(4):696-710.

83. Rao CV. Immunocytochemical localization of gonadotropin and gonadal steroid receptors in human pineal glands. JClin Endocrinol Metab. 1997;82(8):2756-7.

84. Rao CV. The role of human chorionic gonadotropin and cAMP protein kinase A signaling in the differentiation of human endometrial stromal cells. J Clin Endocrinol Metab. 2001;86(8):4000-1.

85. Rao CV. Physiological and pathological relevance of human uterine LH/hCG receptors. J Soc Gynecol Investig. 2006;13(2):77-8.

86. Rao CV, Griffin LP, Carman FR, Jr. Prostaglandin F2alpha binding sites in human corpora lutea. J Clin Endocrinol Metab. 1977;44(6):1032-7.

87. Rao CV, Li X, Toth P, Lei ZM. Expression of epidermal growth factor, transforming growth factor-alpha, and their common receptor genes in human umbilical cords. J Clin Endocrinol Metab. 1995;80(3):1012-20.

88. Rao CV, Li X, Toth P, Lei ZM, Cook VD. Novel expression of functional human chorionic gonadotropin/luteinizing hormone receptor gene in human umbilical cords. JClin Endocrinol Metab. 1993;77(6):1706-14.

89. Reshef E, Lei ZM, Rao CV, Pridham DD, Chegini N, Luborsky JL. The presence of gonadotropin receptors in nonpregnant human uterus, human placenta, fetal membranes, and decidua. J Clin Endocrinol Metab.1990;70(2):421-30.

90. Shi QJ, Lei ZM, Rao CV, Lin J. Novel role of human chorionic gonadotropin in differentiation of human cytotrophoblasts. Endocrinology. 1993;132(3):1387-95.

91. Strott CA, Yoshimi T, Ross GT, Lipsett MB. Ovarian physiology: relationship between plasma LH and steroidogenesis by the follicle and corpus luteum; effect of HCG. J Clin Endocrinol Metab. 1969;29(9):1157-67.

92. Toth P, Li X, Rao CV, Lincoln SR, Sanfilippo JS, Spinnato JA, 2nd, et al. Expression of functional human chorionic gonadotropin/ human luteinizing hormone receptor gene in human uterine arteries.J Clin Endocrinol Metab. 1994;79(1):307-15.

93. Toth P, Lukacs H, Gimes G, Sebestyen A, Pasztor N, Paulin F, et al Clinical importance of vascular LH/hCG receptors-a review. Reprod Biol. 2001;1(2):5-11.

94. Wasowicz G, Derecka K, Stepien A, Pelliniemi L, Doboszynska $\mathrm{T}$, Gawronska B, et al. Evidence for the presence of luteinizing hormone-chorionic gonadotrophin receptors in the pig umbilical cord. J Reprod Fertil. 1999;117(1):1-9.

95. Yeko TR, Khan-Dawood FS, Dawood MY. Human corpus luteum: luteinizing hormone and chorionic gonadotropin re- ceptors during the menstrual cycle. I Clin Endocrinol Metab. 1989;68(3):529-34

96. Zuo J, Lei ZM, Rao CV. Human myometrial chorionic gonadotropin/luteinizing hormone receptors in preterm and term deliveries. J Clin Endocrinol Metab. 1994;79(3):907-11.

97. Zygmunt M, Herr F, Keller-Schoenwetter S, Kunzi-Rapp K, Munstedt K, Rao CV, et al. Characterization of human chorionic gonadotropin as a novel angiogenic factor. J Clin Endocrinol Metab. 2002;87(11):5290-6.

98. Zygmunt M, Herr F, Munstedt K, Lang U, Liang OD. Angiogenesis and vasculogenesis in pregnancy. EurJ Obstet Gynecol Reprod Biol. 2003;110 Suppl 1:S10-8.

99. Edwards DR, Murphy G, Reynolds JJ, Whitham SE, Docherty AJ, Angel $P$, et al. Transforming growth factor beta modulates the expression of collagenase and metalloproteinase inhibitor. EMBO J.1987;6(7):1899-904.

100. Fisher SJ, Cui TY, Zhang L, Hartman L, Grahl K, Zhang GY, et al. Adhesive and degradative properties of human placental cytotrophoblast cells in vitro. J Cell Biol.1989;109(2):891-902.

101. Knittel T, Mehde M, Kobold D, Saile B, Dinter C, Ramadori G. Expression patterns of matrix metalloproteinases and their inhibitors in parenchymal and non-parenchymal cells of rat liver: regulation by TNF-alpha and TGF-beta1. J Hepatol. 1999;30(1):4860

102. Qureshi HY, Sylvester J, El Mabrouk M, Zafarullah M. TGF-betainduced expression of tissue inhibitor of metalloproteinases-3 gene in chondrocytes is mediated by extracellular signal-regulated kinase pathway and Sp1 transcription factor. J Cell Physiol. 2005;203(2):345-52.

103. Staun-Ram E, Shalev E. Human trophoblast function during the implantation process. Reprod Biol Endocrinol. 2005;3:56.

104. Stetler-Stevenson WG, Brown PD, Onisto M, Levy AT, Liotta LA. Tissue inhibitor of metalloproteinases-2 (TIMP-2) mRNA expression in tumor cell lines and human tumor tissues. I Biol Chem. 1990;265(23):13933-8.

105. Norwitz ER, Schust DJ, Fisher SJ. Implantation and the Survival of Early Pregnancy. New Engl J Med. 2001;345(19):1400-8.

106. Semprini AE, Simoni G. Not so inefficient reproduction. Lancet. 2000;356(9225):257-8.

107. Cole LA. Pregnancy failure. J Reprod Immunol. 2012:[Epub A head of Print].

108. Cole LA, Shahabi S, Oz UA, Bahado-Singh RO, Mahoney MJ. Hyperglycosylated human chorionic gonadotropin (invasive trophoblast antigen) immunoassay: A new basis for gestational Down syndrome screening. Clin Chem.1999;45(12):2109-19.

109. Weinans MJ, Butler SA, Mantingh A, Cole LA. Urinary hyperglycosylated hCG in first trimester screening for chromosomal abnormalities. Prenat Diagn. 2000;20(12):976-8.

110. Bahado-Singh RO, Oz AU, Kingston JM, Shahabi S, Hsu CD, Cole L. The role of hyperglycosylated hCG in trophoblast invasion and the prediction of subsequent pre-eclampsia. Prenat Diagn. 2002;22(6):478-81.

111. Goldman-Wohl D, Yagel S. Regulation of trophoblast invasion: from normal implantation to pre-eclampsia. Mol Cell Endocrinol. 2002;187(1-2):233-8.

112. Redman CW, Sargent IL. Latest advances in understanding preeclampsia. Science. 2005;308(5728):1592-4.

113. Cunnane SC, Harbige LS, Crawford MA. The importance of energy and nutrient supply in human brain evolution. Nutr Health. 1993;9(3):219.

114. Gibbons A. Solving the brain's energy crisis. Science. 1998;280(5368):1345-7.

115. Martin RD. Scaling of the mammalian barrier: the maternal energy hypothesis. News Physiol Sci. 1996;4:149-54.

116. Cole LA. Evolution of hCG, evolution of humans and evolution of human pregnancy disorders and cancer. In: Cole LA(ed), Human chorionic gonadotropin (hCG). Elsevier, Burlington MA. 2010:361276.

117. Maston GA, Ruvolo M. Chorionic gonadotropin has a recent origin within primates and an evolutionary history of selection. Mol Biol Evol. 2002;19(3):320-35.

118. Bambra CS. Purification and properties of baboon chorionic go- 
nadotrophin. J Reprod Fertil.1987;79(2):421-30.

119. Crawford RJ, Tregear GW, Niall HD. The nucleotide sequences of baboon chorionic gonadotropin beta-subunit genes have diverged from the human. Gene.1986;46(2-3):161-9.

120. Cassels JW, Jr., Mann K, Blithe DL, Nisula BC, Wehmann RE. Reduced metabolic clearance of acidic variants of human choriogonadotropin from patients with testicular cancer. Cancer. 1989;64(11):2313-8

121. Rosa C, Amr S, Birken S, Wehmann R, Nisula B. Effect of desialylation of human chorionic gonadotropin on its metabolic clearance rate in humans.JClin Endocrinol Metab.1984;59(6):1215-

122. Jauniaux E, Poston L, Burton GJ. Placental-related diseases of pregnancy: involvement of oxidative stress and implications in human evolution. J Clin Endocrinol Metab. 2006;12(6):747-55.

123. Kliman HJ. Uteroplacental blood flow. The story of decidualization, menstruation, and trophoblast invasion. Am J Pathol. 2000;157(6):1759-68.

124. Martin RD. Relative brain size and basal metabolic rate in terrestrial vertebrates. Nature.1981;293(5827):57-60.

125. Martin RD. Human reproduction: a comparative background for medical hypotheses. J Reprod Immunol. 2003;59(2):111-35.

126. Robillard PY, Hulsey TC, Dekker GA, Chaouat G. Preeclampsia and human reproduction. An essay of a long term reflection. $J$ Reprod Immunol. 2003;59(2):93-100.

127. Luckett WP. Comparative development and evolution of the placenta in primates. Contrib Primatol. 1974;3:142-234

128. Odell WD, Griffin J. Pulsatile secretion of chorionic gonadotropin during the normal menstrual cycle. J Clin Endocrinol Metab. 1989;69(3):528-32.

129. Cole LA, Gutierrez JM. Production of human chorionic gonadotropin during the normal menstrual cycle. J Reprod Med. 2009;54(4):245-50.

130. Cole LA. "Background" human chorionic gonadotropin in healthy, nonpregnant women. Clin Chem. 2005;51(10):1765-6.

131. Cole LA, Laidler LL, Muller CY. USA hCG reference service, 10-year report. Clin Biochem. 2010;43(12):1013-22.

132. Snyder JA, Haymond S, Parvin CA, Gronowski AM, Grenache DG Diagnostic considerations in the measurement of human chorionic gonadotropin in aging women. Clin Chem. 2005;51(10):1830-

133. Gronowski AM, Fantz CR, Parvin CA, Sokoll LJ, Wiley CL, Wener $\mathrm{MH}$, et al. Use of serum FSH to identify perimenopausal women with pituitary hCG. Clin Chem. 2008;54(4):652-6.

134. Laub M, Jennissen HP. Identification of the anthelix motif in the TGF- superfamily by molecular 3D-Rapid Prototyping. Materialwissenschaft und Werkstofftechnik. 2003;34(12):1113-9.

135. Lehnert SA, Akhurst RJ. Embryonic expression pattern of TGF beta type-1 RNA suggests both paracrine and autocrine mechanisms of action. Development.1988;104(2):263-73.

136. Acevedo HF, Tong JY, Hartsock RJ. Human chorionic gonadotropin beta subunit gene expression in cultured human fetal and cancer cells of different types and origins. Cancer. 1995;76(8):1467-75

137. Bellet D, Lazar V, Bieche I, Paradis V, Giovangrandi Y, Paterlini P, et al. Malignant transformation of nontrophoblastic cells is associated with the expression of chorionic gonadotropin beta genes normally transcribed in trophoblastic cells. Cancer Res. 1997;57(3):516-23.

138. Bepler G, Jaques G, Oie HK, Gazdar AF. Human chorionic gonadotropin and related glycoprotein hormones in lung cancer cell lines. Cancer Lett. 1991;58(1-2):145-50.

139. Butler SA, Iles RK. Ectopic human chorionic gonadotropin beta secretion by epithelial tumors and human chorionic gonadotropin beta-induced apoptosis in Kaposi's sarcoma: is there a connection? Clin Cancer Res. 2003;9(13):4666-73.

140. Butler SA, Iles RK. Biological function of the free $\beta$-subunit: expression and treatment target in cancer. Elsevier, Burlington MA. 2010:153-71.

141. Cole LA, Birken S, Sutphen S, Hussa RO, Pattillo RA. Absence of the $\mathrm{COOH}$-terminal peptide on ectopic human chorionic gonadotropin beta-subunit (hCG beta). Endocrinology.1982;110(6):2198
200.

142. Cole LA, Schwartz PE, Wang YX. Urinary gonadotropin fragments (UGF) in cancers of the female reproductive system. I. Sensitivity and specificity, comparison with other markers. Gynecol Oncol. 1988;31(1):82-90.

143. Cole LA, Tanaka A, Kim GS, Park SY, Koh MW, Schwartz PE, et al. Beta-core fragment (beta-core/UGF/UGP), a tumor marker: a 7-year report. Gynecol Oncol.1996;60(2):264-70.

144. Cook A, Huddart R, Jay G, Norman A, Dearnaley D, Horwich A. The utility of tumour markers in assessing the response to chemotherapy in advanced bladder cancer. Brj cancer. 2000;82(12):1952.

145. Cosgrove DE, Campain JA, Cox GS. Chorionic gonadotropin synthesis by human tumor cell lines: examination of subunit accumulation, steady-state levels of mRNA, and gene structure. Biochim Biophys Acta. 1989;1007(1):44-54.

146. Gillott D, Iles RK, Chard T. The effects of beta-human chorionic gonadotrophin on the in vitro growth of bladder cancer cell lines. Br J Cancer. 1996;73(3):323.

147. Iles R. Human chorionic gonadotrophin and its fragments as markers of prognosis in bladder cancer. Tum Mark Upd. 1995;7:161-6.

148. Iles RK. Ectopic hCGbeta expression by epithelial cancer: malignant behaviour, metastasis and inhibition of tumor cell apoptosis. Mol Cell Endocrinol. 2007;260-262:264-70.

149. Kinugasa M, Nishimura R, Koizumi T, Morisue K, Higashida T, Natazuka T, et al. Combination assay of urinary beta-core fragment of human chorionic gonadotropin with serum tumor markers in gynecologic cancers. Jpn J Cancer Res. 1995;86(8):783-9.

150. Marcillac I, Cottu P, Theodore C, Terrier-Lacombe MJ, Bellet D, Droz JP. Free hCG-beta subunit as tumour marker in urothelial cancer. Lancet.1993;341(8856):1354-5.

151. Muller CY, Cole LA. The quagmire of hCG and hCG testing in gynecologic oncology. Gynecol Oncol. 2009;112(3):663-72.

152. Nishimura R, Baba S, Hasegawa K, Kinugasa M, Okamura M, Kimura A, et al. [Characterization of immunoreactive hCG betasubunit in cultured fluids of the cell lines derived from gynecologic malignant tumors]. Nihon Sanka Fujinka Gakkai Zasshi. 1990;42(11):1471-6.

153. Carter WB, Sekharem M, Coppola D. Human chorionic gonadotropin induces apoptosis in breast cancer. Breast Cancer Res Treatm. 2006;100:S243-S4.

154. Schwartz PE, Chambers JT, Taylor KJ, Cole LA, Makuch R. Urinary gonadotropin fragments. Anticancer Res. 1993;13:1722-5.

155. Ozturk M, Bellet $\mathrm{D}$, Isselbacher KJ, Wands J. Ectopic beta-human chorionic gonadotropin production by a human hepatoma cell line (FOCUS): isolation and immunochemical characterization. Endocrinology. 1987;120(2):559-66.

156. Regelson W. Have we found the "definitive cancer biomarker"? The diagnostic and therapeutic implications of human chorionic gonadotropin-beta expression as a key to malignancy. Cancer. 1995;76(8):1299-301.

157. Rosen SW, Calvert I, Weintraub BD, Tseng JS, Rabson AS. Stimulation of N6,O2'-dibutyryl cyclic adenosine 3':5'-monophosphate of ectopic production of the free beta subunit of chorionic gonadotropin by a human brain tumor cell line. Cancer Res. 1980;40(11):4325-8.

158. Ruddon RW, Norton SE. Use of biological markers in the diagnosis of cancers of unknown primary tumor. Semin Oncol. 1993;20(3):251-60.

159. Szturmowicz M, Slodkowska J, Zych J, Rudzinski P, Sakowicz A, Rowinska-Zakrzewska E. Frequency and clinical significance of betasubunit human chorionic gonadotropin expression in non-small cell lung cancer patients. Tumour Biol.1999;20(2):99-104

160. Udagawa Y, Nozawa S, Tsukazaki K, Ohta H, Akiba T, Kurihara S. [Biological properties of two newly established cell lines (SKG3a,3b) from a human uterine cervical epidermoid carcinoma]. Nihon Sanka Fujinka Gakkai Zasshi. 1984;36(2):237-46.

161. Cole LA, Muller CY. Hyperglycosylated hCG in the management of quiescent and chemorefractory gestational trophoblastic diseases. Gynecol Oncol. 2010;116(1):3-9.

162. Khanlian SA, Smith HO, Cole LA. Persistent low levels of human chorionic gonadotropin: A premalignant gestational tropho- 
blastic disease. Am J Obstet Gynecol. 2003;188(5):1254-9.

163. Acevedo HF, Krichevsky A, Campbell-Acevedo EA, Galyon JC, Buffo MI, Hartsock RJ. Flow cytometry method for the analysis of membrane-associated human chorionic gonadotropin, its subunits, and fragments on human cancer cells. Cancer. 1992;69(7):1818-28.

164. Delves PJ, Iles RK, Roitt IM, Lund T. Designing a new generation of anti-hCG vaccines for cancer therapy. Mol Cell Endocrinol. 2007;260-262:276-81.

165. He LZ, Ramakrishna V, Connolly JE, Wang XT, Smith PA, Jones CL, et al. A novel human cancer vaccine elicits cellular responses to the tumor-associated antigen, human chorionic gonadotropin beta. Clin Cancer Res. 2004;10(6):1920-7.

166. Iversen PL, Mourich DV, Moulton HM. Monoclonal antibodies to two epitopes of beta-human chorionic gonadotropin for the treatment of cancer. Curr Opin Mol Ther. 2003;5(2):156-60.

167. Morse MA, Chapman R, Powderly J, Blackwell K, Keler T, Green $J$, et al. Phase I study utilizing a novel antigen-presenting celltargeted vaccine with Toll-like receptor stimulation to induce immunity to self-antigens in cancer patients. Clin Cancer Res. 2011;17(14):4844-53.

168. Moulton HM, Yoshihara PH, Mason DH, Iversen PL, Triozzi PL. Active specific immunotherapy with a beta-human chorionic gonadotropin peptide vaccine in patients with metastatic colorectal cancer: antibody response is associated with improved survival. Clin Cancer Res. 2002;8(7):2044-51.

169. Triozzi PL, Stevens VC. Human chorionic gonadotropin as a target for cancer vaccines. Oncol Rep. 1999;6(1):7-17. 